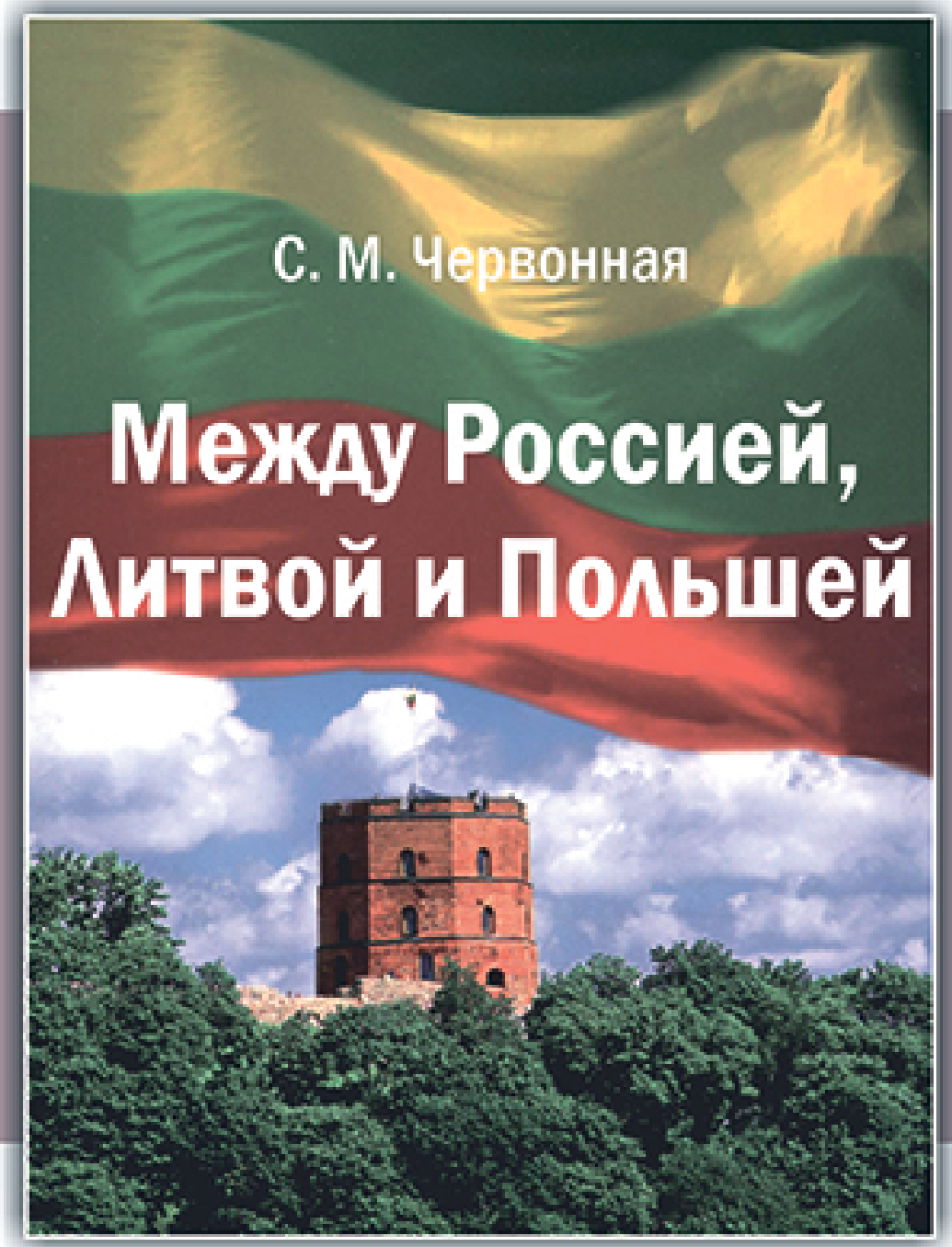




\title{
С.М. Червонная
}

\section{МЕЖДУ РОССИЕЙ, ЛИТВОЙ И ПОЛЫШЕЙ:} судьба художника Вильнюсской школы XX века (жизнь и творчество Стефана Нарембского)

Монография

\author{
Чебоксары
}

Издательский дом «Среда»

2020 
Главный редактор научно-исследовательского проекта «Художественное образование и искусство в Центральной и Восточной Европе в XX и XXI веках. К 100-летию возрождения факультета изобразительных искусств в Вильнюсском университете имени Стефана Батрия» (“Art Education \& Art in Central and Eastern Europe in the 20th and 21st centuries. On the 100th anniversary of the revival of the Faculty of the Fine Arts at the Vilnius Stefan Batory University") - Президент Польского института исследований мирового искусства профессор Ежи Малиновский (Варшава).

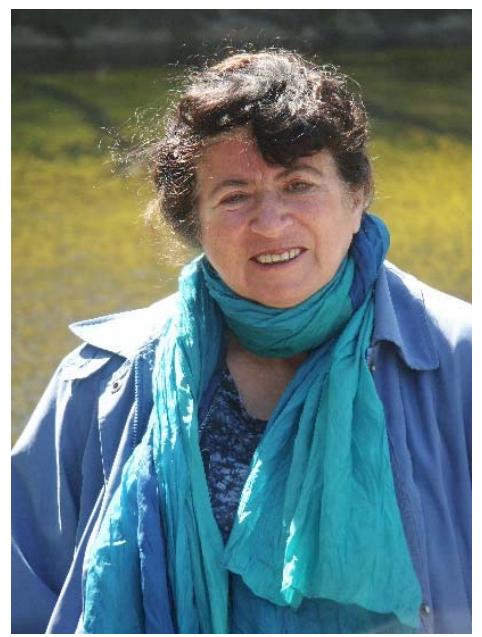

Сведения об авторе:

Светлана Михайловна Червонная (Czerwonnaja Swietłana), доктор искусствоведения (диплом ВАК - 1990), профессор (аттестат ВАК - 2004), выпускница Московского государственного университета им. М.В. Ломоносова (кафедра истории и теории искусства исторического факультета МГУ), до 2004 года - главный научный сотрудник НИИ теории и истории изобразительных искусств Российской академии художеств, с 2004 года - профессор исторического факультета Университета им. Николая Коперника в Торуни (Польша). Почетный доктор (Doctor Honoris Causa) Тбилисского государственного университета им. Ивана Джавахишвили, почетный доктор (Doctor Honoris Causa) Карачаево-Черкесского государственного университета, заслуженный деятель искусств Татарской АССР (Республики Татарстан), член Ассоциации историков искусства и художественных критиков, член Московского союза художников, почетный член Польского института исследований мирового искусства (Варшава). 
УДК 75

ББК 85.14дНарембскийС

Ч-45

\author{
Рецензент \\ д-р искусствоведения, профессор, \\ академик Российской академии художеств
}

Александр Якимович

\begin{abstract}
Червонная C.M.
Ч-45 Между Россией, Литвой и Польшей: судьба художника Вильнюсской школы XX века (жизнь и творчество Стефана Нарембоского): монография / С.М. Червонная. - Чебоксары: ИД «Среда», 2020. - 80 с.
\end{abstract}

\title{
ISBN 978-5-907313-48-4
}

It cannot be said that the creative biography of the artist-architect Stefan Narębski (1892-1966) remains a completely unknown page in the history of art, but everything that has been written and published so far about the life and work of Stefan Narębski is only the top of the iceberg which is his complete biography.

The author restores many forgotten and unknown facts of this biography, mainly based on the materials of the Archive of the Nicolaus Copernicus University, first of all, the artist's own notes ("Diaries"), which had never been published before. Discoveries of this kind relate primarily to the childhood and adolescence of Narębski, held in the Caucasus and Vilnius; his participation in the 1905 revolution; his educational and creative activities in Włocławek in the 1920s; his connections with Stephen Batory University; as well as the repressions that he faced both during the years of the Nazi occupation of Lithuania and during the restoration of Soviet power here, in 1944-45. In the artistic heritage of Narębski, a close-up is highlighted by the types of residential buildings developed by him, educational institutions (museum, school, university department), modern churches, projects for the artistic transformation and decoration of public interiors (the residence of the archbishop; town halls in Vilnius and Torun). The theoretical development of the artistic training program for masters of architectural design (design and decoration of interiors), carried out by Narębski, and the practical implementation of this program at the Nicolaus Copernicus University contained an innovative beginning and provided the most important breakthrough of Polish post-war artistic pedagogy towards a modern, progressive methodology. Of great importance is the international aspect of the work of Narębski, whose personal biography is connected not only with Poland and the strongest impulses of Polish patriotism, but also with Lithuania, Russia, Belarus, Ukraine (with the places where he studied, lived, worked, built and planned the construction of new objects). His contribution to the development of art and artistic pedagogy is subject to measurement on the scale of not only national but also Eastern European culture.

DOI 10.31483/a-192

ISBN 978-5-907313-48-4
(C) Червонная C.M., 2020

(C) Польский институт исследований мирового искусства (куратор проекта), 2020

(C) Наследники Стефана Нарембского и музеи, обладающие произведениями искусства, репродукции которых воспроизведены в книге, 2020

(С ИД «Среда», оформление, 2020 


\section{СОДЕРЖАНИЕ}

1. Историографический контекст, источники

и задачи исследования

2. Детство и отрочество Стефана Нарембского в свете зари, или малой «зорьки» (Pobudki) революции 1905 года...................... 10

3. Первая мировая война и революция: Петроград - Киев Витебск - Орша - Вильнюс... Хождение по мукам (по надеждам молодости)?

4. Варшавская школа и архитектурная практика начала 1920-х годов

5. Влоцлавек (1922-1928): архитектурное возрождение польской провинции

6. Нарембский в польском Вильнюсе (1928 - 1939): связи

с Университетом Стефана Батория и художественное поле творчества.

7. В Литве «под красной звездой» (1940-1941) .............................4 47

8. В Литве под фашистской свастикой (1941-1944) .....................50

9. В «освобожденном» Вильнюсе (1944-1945): из тюрьмы гестаповской в тюрьму НКВД...................................................5

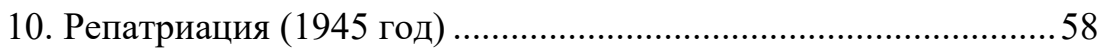

11. Послевоенные годы в Торуни. Университет

Николая Коперника ............................................................... 61

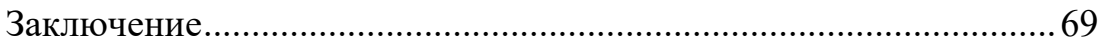

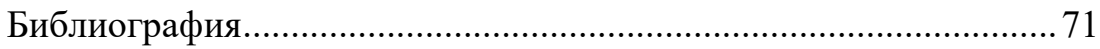

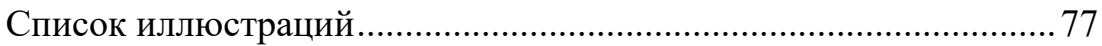




\section{1. ИСТОРИОГРАФИЧЕСКИЙ КОНТЕКСТ, ИСТОЧНИКИ И ЗАДАЧИ ИССЛЕДОВАНИЯ}

Нельзя сказать, что творческая биография художника Стефана Нарембского остается совершенно неизвестной страницей, «белым пятном» в истории искусства Восточной Европы XX века. Его имя включено в словари и справочники, содержащие сведения об архитекторах, работавших в Польше, о преподавателях Университета Стефана Батория в Вильнюсе и Университета Николая Коперника в Торуни ${ }^{1}$; широкое представление о творчестве Нарембского дали посмертные выставки его работ, организованные в Торуни и сопровождаемые изданием научных каталогов (первая - вскоре после смерти художника ${ }^{2}$, вторая - спустя более полувека ${ }^{3}$ ). Его вклад в развитие художественного дизайна, архитектурного проектирования, в науку консервации и реставрации памятников, наконец, в художественную педагогику по достоинству оценен его коллегами и учениками, его современниками и представителями последующих поколений, историками искусства Польши и Литвы.

Если в XX веке искусствоведческая литература, посвященная творчеству Нарембского, была ограничена продукцией польских издательств ${ }^{4}$ и статьями в польской периодике, издаваемой в

1 См. (в хронологической последовательности публикаций): [J. Frycz], Narębski Stefan [в книге:] Polski Stownik Biograficzny, t. 22, Wrocław 1977, c. 540-542; R. Hankowska, Stefan Narębski (1892-1966), artysta malarz, profesor UMK [в книге:] Zastużeni dla Włocławka, red. M. Wojciechowski, Włocławek 1991, с. 147-148; Narębski Stefan [в книге:] Index artystów plastyków absolwentów $i$ pedagogów wyższych uczelni plastycznych oraz członków ZPAP działajacych w latach 1939-1945, Gdańsk - Kraków - Wrocław, 1994, c. 74; Narębski Stefan [в книге:] Encyklopedia Ziemi Wileńskiej, t. I, Wileński stownik biograficzny, red. H. Dubowik, L Malinowski, Bydgoszcz 2002, c. 246; Narębski Stefan [в книге:] 60-lecie Uniwersytetu Mikołaja Kopernika w Toruniu, red. Cz. Łapicz, W. Wróblewski, Toruń 2006, c. 286.

2 Выставке сопутствовало издание каталога: Stefan Narębski. Katalog wystawy, red. J. Frycz, Torun 1967.

3 Stefan Narębski. 1892-1966. Architekt, konserwator, profesor [Katalog wystawy], M. Pszczółkowski (autor katalogu), Toruń 2017. Выставка была открыта в Окружном Музее в Торуни с ноября 2017 до апреля 2018 года.

${ }^{4}$ См. (в хронологическом порядке появления публикаций, персонально посвященных Стефану Нарембскому): B. Mansfeld, Żegnająć Stefana Narębskiego, „Pomorze” (Magazyn społeczno-kulturowy, Bydgoszcz - Toruń) 1966, nr 24, c. 13-14; B. Rymaszewski, Stefan Narębski (1892-1966), Wspomnienia pośmiertne o profesorze Stefanie Narębskim, „Ochrona Zabytków” 1967, nr 2, c. 57-58; J. Frycz, Prof. Stefan Narębski (1892-1966), 
Литве ${ }^{5}$, то в XXI веке его имя появляется в исследованиях литовских историков искусства, обративших свое внимание на польскую художественную культуру Вильнюса 1920-40-х годов ${ }^{6}$. Важнейшим прорывом литовского искусствознания в этом направлении была организация в 2018 году выставки «(Не)видимый Вильнюс: образы искусства и архитектуры» ${ }^{7}$; ее экспонатами были сохранившиеся в музейных и частных собраниях Литвы, в ее библиотеках и архивах произведения художников, главным образом, поляков, живших и работавших в Вильнюсе в период между Первой и Второй мировыми войнами, когда Вильнюс принадлежал Польше (Второй Польской Республике).

Тем не менее все, что до сих пор написано и опубликовано о жизни и творчестве Стефана Нарембского, - это только верхушка того айсберга, каким является его полная биография.

Приступая к восстановлению этой биографии, главным образом, на основе материалов Архива Университета Николая Коперника, в том числе, хранящихся в этом архиве, до сих пор не опубликованных воспоминаний (озаглавленных Дневники (Записки) / Pamiętniki) caмого художника (отпечатанной на машинке рукописи объемом в

„Architektura” 1967, nr 8, c. 336; K. Piwocki, Stefan Narębski, „Biuletyn Historii Sztuki” 1967, nr 3, c. 224-226; K. Górski, Stefan Narębski - architekt, humanista, „Pomorze” 1968, nr 23, c. 68; J. Frycz, Stefan Narębski (1892-1966), architekt, profesor UMK [в книге:] Toruńscy twórcy nauki i kultury (19451958), red. M. Biskup, A. Giziński, Warszawa - Poznań - Toruń 1989, c. 235240; K. Przybyszewski, Z Włocławka do Torunia - przez Wilno, W stulecie urodzin prof. dr. S. Narębskiego, „Nowości” (Toruń) 1992, nr 29, c. 4; A. Churski, Narębski Point, „Nowości” 1998, nr 113, с. 9. Много раз, с большой симпатией и признанием заслуг в разных творческих сферах, вспоминает Нарембского профессор Станислав Лоренц в своем Вильнюсском альбоме, который является важнейшим источником сведений о художественной жизни Вильнюса конца 1920-х - 1930-х годов (St. Lorentz, Album wileńskie, Warszawa 1986, c. 41, 43, 44, 107, 128, 129, 131,132, 147, 176, 203). ${ }^{5}$ См., например: A. Dawidowicz, Profesor Stefan Narębski - projektant, $i$ odnowiciel zabytków Wilna, „Nasza Gazeta” 1996, $\mathrm{nr}$ 43, c. 7-8; B. Znajdziłowska, ,,Ten dom budował mój ojciec...”. „Kurier Wileński”, 1997, nr 160 , c. 1-2.

${ }^{6}$ Cм.: A. R. Čaplinskas, Narembskis Stefanas - architektas, profesorius [в книге:] A. R. Caplinskas, Vilniaus atminimo knyga, Vilnius 2011.

${ }_{7}$ (Ne)matomas Vilnius: tarpukario dailès ir architektūros pavidalai. Parodos katalogas. Vytauto Kasiulio dailès muziejus, $2018 \mathrm{~m}$. liepos $12 \mathrm{~d}$. - rugsèjo 16 d. / (In)visible Vilnius: Shapes of interwar Art and Architecture. Exhibition catalogue. Vytautas Kasiulis Art Museum 12 July - 13 September 2018, red. A. Andriulytė, R. Butvilaitè, I. Mažeikienè, Vilnius 2018. 
42 страницы $)^{8}$, а также других документов, включенных в его Личное дело (Akta Osobowe) ${ }^{9}$, автор руководствуется двумя задачами, имеющими более широкий радиус действия и более важное методологическое значение, чем конкретная задача подробного описания жизненного пути одного художника, включая прежде абсолютно неизвестные или забытые факты, эпизоды и события.

Первой из этих задач является, если можно так сказать, реабилитация самого «биографического жанра» в системе научного искусствознания. В этой системе, в исследованиях и публикациях новейшего времени, центр тяжести все более переносится на анализ самих произведений искусства, на теоретические проблемы, связанные с особенностями художественного процесса, с характером творческих концепций, провозглашаемых манифестов, художественных идеалов. Нельзя сказать, что современное искусствознание возвращается к старому императиву создания «истории искусства без имен» («Kunstgeschicte ohne Künstlernahmen»), обнаружившего свою нежизнеспособность уже в венской школе начала XX века: имена отдельных художников на современных искусствоведческих полотнах встречаются и даже рассыпаны в изобилии, но все меньше внимания уделяется тому, что за этими именами стоит в личном, биографическом плане, каковы жизненный опыт, происхождение, мировоззрение, духовный мир, индивидуальная судьба этих художников. Все это

8 Записки датированы февралем 1963 года. Они не восстанавливают полностью жизненный путь Нарембского, а выделяют крупным планом лишь некоторые отрезки этого пути: семейное происхождение, детство на Кавказе, отроческие годы в Вильнюсе; период работы во Влоцлавке; все, что было пережито в годы немецко-фашистской оккупации и в последние месяцы Второй мировой войны - путь из гестаповской тюрьмы и «трудового лагеря» в тюрьму НКВД и освобождение - случаем, чудом. О жизни и работе художника в Польской Народной Республике (после репатриации 1945 года) там нет ни слова.

${ }^{9}$ Archiwum UMK w Toruniu, K-9/360, Akta osobowe. Narębski Stefan, 19451962. Специфика данного университетского архива заключается в том, что все материалы, собранные в персональных папках («личных делах») преподавателей университета, не имеют описания и нумерации отдельных листов хранения; при ссылке на источник достаточно указания номера папки («личного дела»). Пронумерованы (самим художником) лишь страницы отпечатанной на машинке рукописи Pamiętniki. Даты, указанные на папке, соответствуют периоду работы Нарембского в штате профессорско-преподавательского состава Университета Николая Коперника (от зачисления до ухода на пенсию), при этом папка содержит документы разных лет - от диплома Варшавской Политехники, выданного в 1923 году, до некрологов на смерть Нарембского 1966 года. 
как бы вытесняется на маргинес искусствоведческих исследований, уходит в краткие подстрочные примечания, содержащие даты жизни и указания на школу, в которой учился художник. Между тем, личная жизнь художника - это такой же интересный для историка искусства и имеющий свою самостоятельную ценность материал, как его творчество. Эта жизнь всегда вписана в определенную историческую эпоху со всеми ее катаклизмами, а творчество художника, как предмет исторического исследования, от этой эпохи неотделимо. Многие события на жизненном пути художника, в том числе события, непосредственно к искусству, казалось бы, прямого отношения не имеющие, в конечном итоге чрезвычайно важны для понимания того, как формировалась история искусства того или иного народа, какие личности участвовали в этом процессе.

Вторая задача связана с преодолением национальных границ при исследовании таких феноменов (творчества таких художников), которые в силу сложившихся обстоятельств оказывались в пограничной зоне между разными странами, народами, национальными культурами. Как отмечено выше, того же Нарембского давно и высоко ценило польское искусствознание, причем ценило именно как польского художника и педагога, который внес значительный вклад в систему художественного образования польских университетов (УСБ и $\left.\mathrm{YHK}^{10}\right)$, и только в самое последнее время его стали замечать также литовские искусствоведы, отдавая себе отчет в том, что его творчество имеет большое значение для культуры Вильнюса, а значит и для истории искусства Литвы. Однако, Нарембский жил и работал не только в границах польского государства (Второй Польской Республики / Druga Rzeczpospolita Polska 1920-30-х годов; Польской Народной республики / Polska Republika Ludowa, в которой прошли последние годы его жизни) и не только в границах Литвы (независимой Литовской Республики, которой был возвращен Вильнюс в октябре 1939 года; оккупированной Советским Союзом, а затем нацистским рейхом страны, которую оккупанты пытались превратить в свои марионеточные структуры: «советы»- в Литовскую $\mathrm{CCP}$, немцы - в часть провинции «Остланд»). Его детство прошло на Северном Кавказе, его молодость - в Петербурге, а также в той «Виленской губернии», в которой зрело сильнейшее революцион-

10 Здесь и далее автор пользуется аббревиатурами: УСБ - Университет Стефана Батория в Вильнюсе, УНК - Университет Николая Коперника в Торуни, ОИИ - Отделение изобразительных искусств, существовавшее в структуре этих университетов. 
ное (интернациональное по своему характеру) движение, направленное против Российской империи; в годы Первой мировой войны он служил в российской армии и работал на ее фронтах в Украине (Киеве) и Белоруссии (Витебске). В этом контексте историкам русского искусства и русской культуры следовало бы обратить внимание на польских художников, которые начинали свой жизненный путь на различных окраинах этой империи ${ }^{11}$, так же как европейским историкам искусства Восточной Европы следовало бы обратить более пристальное внимание на драматические судьбы художников - литовцев, поляков, евреев, белорусов, русских, латышей, латгалов, эстонцев, оказавшихся в нацистском «Остланде» 194144 годов. Очень хотелось бы нарушить затянувшееся молчание.

${ }^{11}$ Из истории русского искусства (олицетворенной одноименным академическим изданием и другими обобщающими трудами) имена этих художников практически выпали. К числу редких исключений относится интерес, проявленный казанскими искусствоведами (П.Н. Корнилов, О.Л. Улемнова) к судьбе польского художника Ежи Хоппена, связанный с его пребыванием в Казани в годы революции и гражданской войны; впрочем и этот интерес не нашел еще отражения ни в одной российской публикации; единственная статья с воспоминаниями П.Н. Корнилова о пребывании Хоппена в Казани была опубликована в Варшаве: Piotr Kornilow, Jerzy Hoppen w Kazaniu, „Rocznik Muzeum Narodowego w Warszawie" 1977, XXI, c. 293-300. Даже те польские художники (например, архитектор Стефан / Степан Кричинский, уроженец Виленской губернии, литовский татарин), о которых довольно много написано в специальных исследованиях (в данном случае, в российских исследованиях архитектуры Петербурга начала XX века), обычно фигурируют в таких публикациях как представители «русского искусства» без указания на их национальное происхождение. 


\section{2. ДЕТСТВО И ОТРОЧЕСТВО СТЕФАНА НАРЕМБСКОГО В СВЕТЕ ЗАРИ, ИЛИ МАЛОЙ «ЗОРЬКИ» (РОВUDКІ) РЕВОЛЮЦИИ 1905 ГОДА}

Стефан Нарембский (Stefan Narębski) родился 23 января (по старому календарю) / 5 февраля (по новому календарю) $)^{12} 1892$ года в городе Грозном, в семье польского врача Юзефа Нарембского. Там в конце XIX находилась довольно большая группа ссыльных поляков, обязанных нести службу в российских военных гарнизонах. В их среде живым оставался польский язык, и дети воспитывались в католической вере и в польском патриотическом духе.

Воспоминания о своем детстве, проведенном на Северном Кавказе, художник начинает с эпизода, который может служить ключевым моментом, определяющим формирование его сознания и идентичности. «Местный житель (туземец) Садык, который доставлял нам дрова, однажды привез и отдал маме индюшку, - пишет Нарембский. - Когда мама хотела заплатить, он сказал, что это бакшиш - подарок, ибо Ты, я знаю, не урус (не русская), Ты такая же бедная, как мы». Нарембский комментирует этот эпизод словами: «Это была манифестация солидарности народов, угнетенных Россией (Dostawca drów autochton Saduk kiedyś przywiózł indyka i darował matce. Kiedy matka chciała zapłacić, powiedział, że to 'Bakszysz' - gościniec, bo 'Ty, wiem, nie jestesz urus (Rosjanką). Ty jestesz takąż biedną jak my' [...] Była to manifestacja solidarności narodów ujarzmionych przez Rosją)»» ${ }^{13}$.

«Любовь к рисованию, - вспоминает Нарембский, - я обнаружил еще на Кавказе... Строил из кубиков сложные конструкции; наблюдая за этим, мой отец предсказывал, что стану архитектором (Ochotę do rysunki objawiałem jeszcze na Kaukazie... Budowałem z

12 В некоторых архивных документах и публикациях день рождения художника (по новому стилю) ошибочно указывается как «2 февраля» (иногда как «4 февраля»). Эту ошибку совершал также сам художник, заполняя анкеты и «листки по учету кадров» послевоенного периода.

${ }^{13}$ Archiwum UMK w Toruniu, K-9/360, Akta osobowe. Narębski Stefan, 19451962, Pamiętniki, c. 3. - Здесь и далее все цитаты приводятся в авторском переводе с польского, литовского и английского на русский язык с воспроизведением в скобках оригинального текста - С.Ч. 
klocków skomplikowane budowle, co widząc ojciec mój przepowiadał, że będę architektem)» ${ }^{14}$.

Отец будущего художника получил высшее медицинское образование (звание «полевого хирурга»), служил в Гродно, Вильнюсе, а затем был назначен на должность «старшего врача» в Кизляро-Гребенском казачьем полку, расквартированном в Грозном. Он умер от заражения крови в 1899 году. Мать Констанция Нарембская (из дома Карницких) решила вместе с детьми (у Стефана были брат Пётр и сестра Юстина) и своей матерью («бабушкой Юстиночкой») вернуться в Вильнюсский край, откуда она была родом. После нескольких месяцев, проведенных в родном поместье, они переехали в Вильнюс и поселились в доме родственника матери Оттона Богдановича (Otton Bohdanowicz) на площади Наполеона. Нарембский вспоминает, что из окон его комнаты открывался вид на памятник Муравьеву, у которого постоянно стоял дежурный полицейский ${ }^{15}$.

В этом доме семья жила до 1914 года.

В Вильнюсе Стефан с 1900 года учился в начальной школе Семена Акимовича Ковалюка, а затем в Реальном училище, которое окончил в 1911 году. В своих воспоминаниях Нарембский называет это училище, где преподавание велось на русском языке, «чужой» для него школой («obca szkoła») и сообщает интересные подробности о положении польских учащихся, которые, по его подсчетам, составляли в ту пору не менее половины всей школьной молодежи Вильнюса. В их среде зрели революционные настроения. Их

${ }^{14}$ Archiwum UMK w Toruniu, K-9/360, Akta osobowe. Narębski Stefan, 1945 1962, Pamiętniki, c. 10.

${ }^{15}$ Archiwum UMK w Toruniu, K-9/360, Akta osobowe. Narębski Stefan, 1945 1962, Pamiętniki, c. 9. Никакая стража не могла, однако, удержать жителей Вильнюса от выражения ненависти к палачу («Муравьеву-вешателю»), жертвами которого стали многие герои январского восстания 1863 года (между ними был прадед автора настоящей статьи, арестованный в своем имении в Рославле Смоленской губернии и казненный за поддержку повстанцев). В начале Первой мировой войны власть демонтировала и отправила из Вильнюса в российский тыл памятники Екатерины, Муравьева и Пушкина - эти «единственные свидетельства культурной миссии Российской империи на территории Литвы», как иронично писал об этом позднее профессор Университета Стефана Батория художник-фотограф Ян Булгак, успевший сфотографировать этот момент демонтажа памятников (J. Bułhak, Wiek męski Ferdynanda Ruszczyca [в книге:] Ferdynand Ruszczyc. Życie i dzieto, Wilno 1939, c. 37). 
всплеск приходится на период революции 1905 года. Польские ученики вильнюсского Реального училища отказывались участвовать в православных богослужениях («молились по-польски»), бойкотировали торжества открытия памятника императрицы Екатерины, состоявшиеся в Вильнюсе 4 марта 1905 года. Нарембский вспоминает, что на эти торжества в Вильнюс прибыл Великий князь Михаил (брат императора), присутствовал губернатор СвятополкМирский и несколько зажиточных поляков опозорили свое имя участием в этих торжествах. Для польской молодежи настоящим праздником стало открытие памятника-бюста поэта Адама Мицкевича, который усилиями польской общественности удалось в условиях конспирации соорудить в костеле Св. Яна ${ }^{16}$; к стене, у которой был поставлен этот бюст, ученики вильнюсского Реального училища принесли венок с надписью «От рожденных в неволи, скованных по рукам и ногам учеников Реального училища (Od urodzonych W niewoli, okutych w powiciu uczniów szkoły realnej)»1 ${ }^{17}$.

«Японская война, - пишет Нарембский, - кружила нам головы [...]. Поднималась революционная волна. Я пережил все это очень горячо, с энтузиазмом, всей душой отдаваясь очарованию бунта. Несмотря на свой юный возраст, участвовал в походах от школы к школе с целью добиться участия всех учащихся в школьной забастовке; ходил на митинги (Wojna japońska podniecała umysły. Cieszyły powodzenia Japończyków i zachwiana i ośmieszona

${ }^{16}$ Инициатива создания памятника к 100-летию со дня рождения Адама Мицкевича (отмеченного в декабре 1898 года) принадлежала его сыну Владиславу. Проект мемориального сооружения, предназначенного для интерьера костела, выполнил Тадеуш Стрыйенский (Tadeusz Stryjeński). На средства вильнюсского мецената Юзефа Монтвиллы (Józef Montwiłła) в Париже был приобретен бюст поэта, автором которого был известный скульптор-портретист Марцелий Гуйский (Marceli Gujski / Guyski; см. о нем: Stownik artystów polskich i obcych w Polsce dziatajacych, Wrocław Warszawa - Kraków - Gdańsk, t. 2, с. 527). Этот бюст был включен в композицию мемориала. Монтажные работы велись в тайне от городских властей, за занавеской, скрывавшей стену костела. После открытия памятника ксёндз-настоятель костела Казимир Пацынко (Kazimierz Pacynko), допустивший это самовольное сооружение, был подвергнут штрафу, но памятник остался в костеле (подробно история его сооружения освещена в статье: P. Szubert, Pomnik Mickiewicza w Wilnie, „Blok-Notes Muzeum Literatury im. A. Mickiewicza w Wilnie" 1988, nr 9, c. 195-236).

${ }^{17}$ Archiwum UMK w Toruniu, K-9/360, Akta osobowe. Narębski Stefan, 19451962, Pamiętniki, c. 17. 
powaga zaborcy. Rosła fala rewolucyjna. Przeżyłem to wszystko na gorąco, całkowicie i entuzjastycznie oddany urokowi buntu. Brałem mimo b. młodego wieku udział w pochodach od szkoły do szkoły w celu wymuszenia od uczniów wszystkich szkół udziału w strajku szkolnym. Chodziłem na wiece) $){ }^{18}$.

Вместе со своими товарищами Нарембский участвовал в 1905 году в школьной забастовке, парализовавшей на некоторое время учебный процесс в Вильнюсской губернии ${ }^{19}$, а затем в деятельности подпольных кружков и молодежных организаций. В Вильнюсе действовали две подпольные организации - «Реt» (для учащихся средних школ) и «Zet» (для учащихся высших учебных заведений). Нарембский вступил в «Pet» в 1907 году. «Эта патриотическая, имевшая демократический характер организация, - писал он, - вела важную работу в области самообразования и воспитания польской молодежи. Я уже с 1905 года с головой погрузился в работу этой ученической организации; руководил школьным кружком, который каждое воскресенье собирался в квартире моей матери; [...] был заместителем предводителя всего союза [Pet] на территории Вильнюса (Ta patriotyczna o tendencjach demokratycznych organizacja prowadziła poważną akcję samokształceniową i wychowawczą. Od r. 1905 pogrążyłem się w pracach tej uczenikowskiej organizacji Prowadziłem kółko sztubeckie zbierające się co niedzielę w mieszkaniu mojej matki [...] byłem wiceprzewodniczący całego związku [Pet] na terenie Wilna)» ${ }^{20}$. Члены этого конспиративного кружка caмостоятельно изучали польскую историю и литературу, собрали в этих целях целую тайную библиотеку. Установив связи с действовавшим в Вильнюсе Товариществом любителей наук (Towarzyszenie Przyjaciół Nauk), кружковцы получили под его крышей уголок для своих занятий и с большим энтузиазмом обратились к вопросам охраны памятников польской культуры в Вильнюсе.

Позднее, уже из Петербурга, где Нарембский учился в Институте гражданских инженеров, он поддерживал тесные связи с „Zet”,

18 Ibid., c. 17.

19 В 1930 году в Вильнюсе были организованы торжества, посвященные 25-летию этой школьной забастовки, и Нарембский, среди других ее участников, получил почетный знак «борца за польскую школу» (“ $\mathrm{Za}$ walkę o szkołę polską").

${ }^{20}$ Archiwum UMK w Toruniu, K-9/360, Akta osobowe. Narębski Stefan, 1945 1962, Pamiętniki, c. 18. 
в 1914 году был делегатом тайного съезда „Zet”, созванного в Кракове, на котором было принято решение о бойкоте поляками всех русских учебных заведений на территории Королевства Польского.

Члены „Реt” собирались в Вильнюсе в редакции газеты „Pobudka” («Зорька») - единственного легального издания, отвечавшего прогрессивным чаяниям польской вильнюсской молодежи, которым руководил Леон Перковский (Leon Perkowski). B «Побудке» Нарембский начал печататься, опубликовав в 1907 году первое свое стихотворение Старый двор, посвященное повстанцам 1863 года. К этому периоду относятся первые встречи юного Нарембского с художниками вильнюсского круга. Он лично знал Александра Корбута, Болеслава Русецкого (которому к тому времени исполнилось 90 лет), Хованьчака, который позднее, во время Первой мировой войны, пытался бежать из царской России через Финляндию (финны задержали его на границе в 1916 году). Разумеется, тот польский художественный Вильнюс начала XX века, которым живо интересовался молодой Нарембский, уже ощущая свою личную причастность к нему, не имел ничего общего с кругом воспитанников и преподавателей печально известной Рисовальной школы Ивана Трутнева, созданной с целью русификации вильнюсской культуры. Нарембский был как раз одним из тех юных «бунтовщиков», грязные карикатуры на которых рисовал И.В. Трутнев в своих картинах-пасквилях на революцию 1905 года. 


\section{3. ПЕРВАЯ МИРОВАЯ ВОЙНА И РЕВОЛЮЦИЯ: ПЕТРОГРАД - КИЕВ - ВИТЕБСК - ОРША - ВИЛЬНЮС... ХОЖДЕНИЕ ПО МУКАМ (ПО НАДЕЖДАМ МОЛОДОСТИ)?}

Профессиональное архитектурное образование Стефан получил в Институте гражданских инженеров в Петербурге (Петрограде), где учился в 1911-1916 годах. До обретения Польшей независимости в 1918 году и до восстановления традиций высшего архитектурного образования в самой Польше этот Институт был основной Alma Mater польских зодчих, вступающих в активную творческую жизнь в начале XX века. Его воспитанниками были такие известные архитекторы польского происхождения, как Юзеф Гославский / Józef Gosławski (1865-1904), Казимир Скуревич / Kazimierz Skórewicz (1866-1950), Юзеф Плошко / Józef Płoszko (1867-1931), Стефан Кричинский / Stefan Kryczyński (1874-1923) ${ }^{21}$. Многие из них внесли значительный вклад в развитие архитектуры первой половины XX века; их проекты были реализованы во многих регионах бывшей Российской империи, начиная от ее столицы, где особенно заметный след оставил Стефан Кричинский, и кончая дальними северными, восточными и южными «окраинами», среди которых особенно выделялось Закавказье - Тифлис и в еще большей степени Баку, где работала целая плеяда талантливых польских архитекторов. Стефан Нарембский был одним из самых младших в этой группе польских воспитанников Института гражданских инженеров, которым после окончания Первой мировой войны и революционных потрясений в России предстояло работать уже в новых условиях и в новых государствах, естественно, прежде всего во Второй Польской Республике, куда возвращались все представители польской интеллигенции, которым удавалось вырваться из большевистской «страны советов».

${ }^{21}$ Круг славных имен польских архитекторов - воспитанников этого Института (включая имя Стефана Нарембского) вписан в Памятную книгу, изданную «кружком гражданских инженеров», сформировавшимся при Товариществе польских техников (Stowarzyszenie Techników Polskich); см.: Księga Pamiątkowa Inżynierów Cywilnych Polaków wychowanków Instytutu Inżynierów Cywilnych w Petersburgu, Warszawa 1937. Нарембский был одним из основателей землячества польских студентов в этом Институте. 
Формально Институт он не окончил, а прервал занятия в 1916 году ${ }^{22}$, поступил на военную службу и был направлен из Петрограда в Киев, где работал инженером-техником Юго-Западного фронта, занимаясь строительством гидросооружений. Из Киева его в 1917 году перевели в Витебск, где он работал инженером-техником Двинского военного округа.

В мировоззрении Нарембского в 1917-1918 годах происходит важнейший перелом от юношеского революционного максимализма к трезвой оценке происходящих в стране перемен. Если в отрочестве он был увлечен идеалами революции 1905 года, а в студенческие годы в Петербурге проявлял интерес к деятельности имевшей здесь свою резиденцию рабочей партии "СДКПиЛ - Социал-демократия Королевства Польского и Литвы" ("SDKPiL Socjaldemokracja Królestwa Polskiego i Litwy"), о чем он мельком вспоминает в своих Записках ${ }^{23}$, то столкнувшись с реальным обликом большевистской революции (уже не в Петрограде, а в Белоруссии), он понимает, что это - не его революция, не то освобождение угнетенных народов империи, о котором он мечтал. Весной 1918 года он уезжает из Витебска, уже готового погрузиться в советское безумие ${ }^{24}$, и возвращается в Польшу, провозгласившую 11 ноября этого года восстановление своей государственности и независимости. Он становится последовательным и горячим патриотом Второй Польской Республики, готовым отдать ей все свои силы, талант и творческие замыслы.

22 В своей Автобиографии, написанной 3 июня 1950 года в Торуни, Нарембский пишет, что «прервал занятия в связи с материальными трудностями» (Archiwum UMK w Toruniu, K-9/360, Akta osobowe. Narębski Stefan, 1945-1962). Не исключено, что, принимая решение о переходе, по его собственному выражению, «в кабалу» - на армейскую службу, Нарембский исходил не только из «материальных трудностей», с которыми он столкнулся в военные годы в Петрограде, но также из опасений репрессий, которым он мог быть подвергнут за свою конспиративную и революционную деятельность в студенческие годы.

${ }_{23}^{23}$ Archiwum UMK w Toruniu, K-9/360, Akta osobowe. Narębski Stefan, 19451962, Pamiętniki, c. 31.

24 «Попал я в армейскую кабалу, и только весной 1918 года, - пишет он, - в том хаосе, который там творился, мне предоставилась возможность уехать вместе с моей семьей из Витебска через Оршу и вернуться в наше деревенское имение Вазгинишки... (Zakabaliłem się w wojsku, i dopiero wiosną 1918 roku miałem możność $\mathrm{w}$ zaistniałym chaosie z Witebsku przez Orszę z rodziną wrócić na wieś do naszych Wazginiszek)»" (Archiwum UMK w Toruniu, K-9/360, Akta osobowe. Narębski Stefan, 1945-1962, Pamiętniki, c. 30). 


\section{4. ВАРШАВСКАЯ ШКОЛА И АРХИТЕКТУРНАЯ ПРАКТИКА НАЧАЛА 1920-Х ГОДОВ}

С мая 1918 года Нарембский живет в Вильнюсе, в 1919 году поступает на архитектурное отделение Варшавской Высшей Политехнической школы и завершает учебу в декабре 1922 года. Диплом Политехники Варшавской (№ 179), подтверждающий, что он сдал все предусмотренные программой обучения экзамены с общей оценкой «хорошо», исполнил дипломную работу в области сельского проектирования и ему присвоено звание «дипломированного архитектора» («architekt dyplomowany”), был выдан ему 31 августа 1923 года ${ }^{25}$. Учебу в Варшаве Нарембский совмещает с работой в фирме, занимавшейся строительством «репрезентативных зданий» (Biuro Budowy Gmachów Reprezentacyjnych) под руководством архитектора Марьяна Лялевича (Marian Lalewicz), в частности, принимает участие в перестройке бывшего Дворца наместника в здание, предназначенное для Президиума Совета Министров.

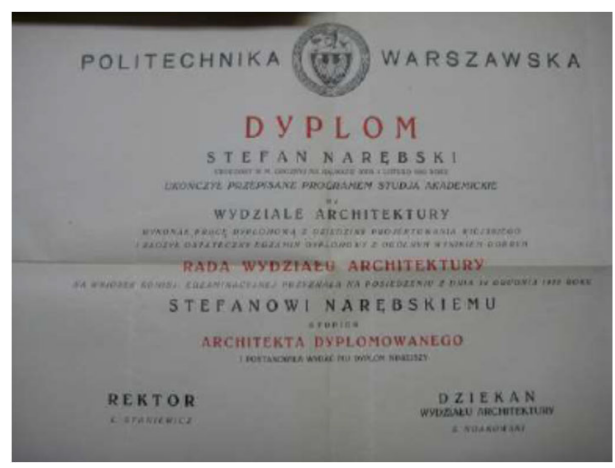

Илл. 1. Диплом Варшавского Политехнического Института (выдан в 1923 г.) о присуждении Стефану Нарембскому звания дипломированного архитектора

С задачами нового строительства в разрушенной войной стране был связан разработанный Нарембским (в период его учебы в Вар-

${ }^{25}$ Подлинный документ, подписанный деканом Отделения Архитектуры Варшавской Политехники архитектором С. Ноаковским, хранится в Архиве УНК в Личном деле С. Нарембского. 
шавской Политехнике) проект типового дома врача для малого городка (1922; хранится в Музее архитектуры во Вроцлаве). Проект предусматривал предельно «экономное» по своим затратам и размерам сооружение одноэтажного дома с мансардой, однако эта «экономность» не означала аскетизма. Напротив, пластичное арочное оформление портала, оконных наличников, рисунок высокой крыши, крытой черепицей и взрезанной слуховыми окошками; предназначенный для рельефного украшения тимпан высокого треугольного фронтона над входом и другие детали свидетельствовали о желании архитектора придать этому сооружению по-своему репрезентативный характер, подчеркнуть его значение в архитектурном ансамбле, а следовательно и в общественной жизни маленького поселка или городка. При этом все средства наружного украшения дома (формы выступающего вперед портика, портала, окон, крыши) должны были вызывать ассоциации с традициями архитектуры польской провинции, прежде всего с духом вильнюсского барокко.

Считая это произведение в высшей степени характерным для зодчества первых лет после восстановления независимости Польской Республики, Михал Пшчулковский подчеркивает, что типичным для этого периода было решительное обращение архитекторов к традициям польской архитектуры, господствовавшим до «разборов» Польши и столь же решительное игнорирование всего (особенно наиболее бросающихся в глаза примет), связанного с развитием архитектуры на этих землях на протяжении 120 лет российского, австрийского и прусского господства ${ }^{26}$. Если «традиционалистское» направление, с которого начинал и к которому постоянно возвращался в своем творчестве Нарембский, вело в прошлое, то этим прошлым был никак не XIX век и не начало XX века, а XVII-XVIII века, овеянные романтикой своего особенного (отечественного, национального) прекрасного прошлого.

К стилю эпохи последнего польского короля Станислава Августа (к так называемому «станиславовскому стилю») обращается Нарембский также в своем проекте перестройки имения в Кузницах (Kuźnice; 1922; хранится в Музее архитектуры во Вроцлаве).

26 Stefan Narębski. 1892-1966. Architekt, konserwator, profesor [Katalog wystawy], autor katalogu M. Pszczółkowski, Toruń 2017, c. 9. 
Как и дом врача, это тоже, при всей его индивидуальной неповторимости, типичный проект частного дома, дворянского имения, скромного, но красивого и изящно украшенного (портик с треугольным фронтоном и тимпаном, предназначенным для лепнины; пилястры по углам здания; оконные наличники; высокая черепичная крыша), напоминающий о достойном прошлом его владельцев и обитателей, которым возвращаются их права и достоинство в новой, возрожденной стране.

Очень рано, однако, Нарембский сталкивается с задачами проектирования таких сооружений, подобных которым не было в истории давней польской архитектуры и возведение которых было вызвано новыми обстоятельствами промышленного, транспортного, торгового развития республики. Для таких сооружений надо было искать новые, нетипичные формы, мало напоминающие жилые дома, загородные имения, костелы и другие объекты традиционного городского и сельского пейзажа «старой» Польши. Для «новой» Польши Нарембский проектирует выставочный павильон Варшавского сельскохозяйственного синдиката (Pawilon Syndykatu Rolniczego Warszawskiego; 1923; Музей архитектуры во Вроцлаве), придумывая экзотическое сооружение, отдаленно напоминающее буддистскую пагоду. 


\section{5. ВЛОЦЛАВЕК (1922 - 1928): АРХИТЕКТУРНОЕ ВОЗРОЖДЕНИЕ ПОЛЬСКОЙ ПРОВИНЦИИ}

Новый период в жизни и творчестве Нарембского начинается после окончания Варшавской Политехники с его переездом в город Влоцлавек Куявского воеводства - на запад Польши.

Здесь он активно включается в местную общественную и культурную жизнь, работает в проектном бюро своего тестя инженера Антония Ольшаковского ${ }^{27}$, в 1925-26 годах преподает рисунок во влоцлавской Гимназии имени Длугоша. Нарембский становится одним из организаторов регионального отделения Польского Товарищества краеведов (Polskie Towarzystwo Krajoznawców), издателем и редактором ежемесячного журнала, посвященного общественным, экономическим, просветительским и художественным проблемам, «Жизнь Влоцлавка и его окрестностей» ("Życie Włocławka i Okolicy", Miesięcznik poświęcony sprawom społecznym, ekonomicznym, oświatowym i artystycznym). Издание журнала начинается в 1926 году, и в его выходных данных указано: „Издатель инженер Стефан Нарембсктй (Wydawca: inż. Stefan Narębski)".

Во Влоцлавке в это время сложился круг польских интеллигентов, имевших в прошлом свой «революционный» опыт: председатель местного Городского Совета доктор Витольд Пясецкий (Witold Piasecki), который был давным коллегой Нарембского по подпольной студенческой организации «Zet»; бывший каторжанин Эдмунд Плоцкий (Edmund Płocki), который много лет провел в Сибири и на Камчатке (Нарембский характеризует его в своих Записках как «прекрасный образец старого борца за лучшее будущее / piękny typ starego bojowca o lepsze jutro»); преподаватели лицея, журналисты. Совместными силами влоцлавские интеллектуалы развернули многогранную деятельность и немало сделали для просвещения молодежи, для охраны природных богатств (курортной зоны серно-водородных источников «Венец / Wieniec») и архитектурного преобразования Влоцлавка в город современной урбанистики.

${ }^{27}$ В брак с Софьей Ольшаковской он вступает в Варшаве 28 сентября 1918 года. 
Проблемы, которые поднимали в своих статьях авторы журнала «Жизнь Влоцлавка и его окрестностей», далеко выходили за границы узких провинциальных интересов, касались не только «всей Польши», но можно сказать, «всего мира». Так, статья Капитал $u$ $m p y d^{28}$ была серьезной попыткой ревизии марксистского учения; в статье Славянские наииональные меньшинства в Польше ${ }^{29}$ ставились особо острые и болезненные для многонационального уклада Второй Польской Республики проблемы. Главной задачей издания, которую сформулировал С. Нарембский в редакционной статье, открывающей второй номер журнала, была выработка платформы гражданского согласия, преодоления партийной ограниченности в политике и культуре, привлечения широких слоев интеллигенции к конструктивной, позитивной, созидательной работе на благо польского народа и государства. «Со времен войны и споров, связанных с выбором ориентации, в нашем обществе продолжается раскол, выходящий за границы нормальных партийных дискуссий (Od czasu wojny i sporów orientacyjnych trwa w społeczeństwie naszym rozbicie, przekraczające charakter zwykłych sporów partyjnych)», - с горечью писал Нарембский и выражал от имени редакции пожелание «всем нашим партиям наиболее активного участия в их работе интеллигенции, которая должна внести в жизнь этих конкурирующих между собой партий конструктивное начало и элемент доброй воли (stronnictwom naszym jak największego udziału inteligencji; niech wnosi ona element rzeczowy i element dobrej woli w stosunku rywalizujących stronnictw) $\rangle^{30}$.

Нарембский использовал журнал также как трибуну для манифестации новых подходов к задачам градостроительства в независимой Польше и для апробации некоторых собственных проектов в области строительства и архитектурного дизайна. Так, в статье 3 а раициональную застройку пригородов Влоилавка ${ }^{31}$ Нарембский поднимает актуальные вопросы жилищного строительства в их тесной связи с

${ }^{28}$ L. Starzyński, Kapitat i praca, „Życie Włocławka i Okolicy” 1926 (listopad), nr 2, c. 11-12.

${ }^{29}$ J. Hołyński, Słowiańskie mniejszości narodowe w Polsce, „Życie Włocławka i Okolicy" 1926 (listopad), nr 2, c. 9-11.

${ }^{30}$ [S. Narębski, Od redakcji], „Życie Włocławka i Okolicy” 1926 (listopad), nr 2 , c. 2 .

${ }^{31}$ S. Narębski, O racjonalne zabudowanie przedmieść Włocławka, „Życie Włocławka i Okolicy” 1926 (październik), nr 1, c. 7-9. 
экономической рациональностью, эстетикой, удобством и комфортом для человека, охраной окружающей среды. Профессиональный анализ градостроительной системы Влоцлавка и конструктивные предложения по ее прогрессивному развитию содержит в себе статья Нарембского Замечания по поводу планирования и регулирования Влоилавка ${ }^{32}$. С гордостью пишет архитектор о том, что «Влоцлавек, - хотя его непосредственно к тому не вынуждали ни военные разрушения, ни пожары, - кажется, первым из городов бывшей $\mathrm{KoH}$ гресувки [Королевства Польского] понял необходимость введения планового, регулярного начала в городское строительство и исправления ошибок, допущенных прежде. Ныне примеру Влоцлавка последовали Лович, Радом и Люблин (Włocławek, bodaj pierwszy z miast dawnej Kongresówki, bez przynaglenia klęskami i wojny czy pożogi, pomyślał o planowym ujęciu rozbudowy i o naprawieniu błędów w układzie miasta. Dziś za przykładem Włocławka poszły Łowicz, Radom i Lublin)» ${ }^{33}$.

Фундаментальные вопросы стиля, функций, новейших направлений зодчества и градостроительства поднимает Нарембский в своей статье Проблемы и задачи современной архитектуры, формулируя в ней один из важнейших тезисов функционализма о «заслуженном примате конструкции здания над декоративным аппаратом» (zasłużoną przewagę nad aparatem dekoracyjnym w wymowie i estetyce)» ${ }^{34}$. Не будучи сторонником авангардистских направлений в архитектуре 1920-х годов, Нарембский в то же время отдавал себе отчет в необходимости модернизации архитектурного мышления, основанной на преодолении стандартов ордерной системы и культа «исторических стилизаций» ${ }^{35}$. «Благородство пропорций, - писал он в той же статье, - может быть достигнуто без какой-либо сакраментализации ордерных систем классической архитектуры, при этом выявление подлинных эстетических качеств материала и прочность исполнения способны дать гораздо более существенные эффекты, нежели гипсовые безделушки [...] Архитектуре стали доступны новые возможности и цели. Недооценка их и упрямое злоупотребление

${ }^{32}$ S. Narębski, Uwagi nad rozwojem planu i nad regulacja Włocławka, „Życie Włocławka i Okolicy" 1927 (luty), nr 2, c. 6-9.

${ }^{33}$ Ibid., s. 7.

${ }^{34}$ S. Narębski, Zagadnienia architektury nowoczesnej, „Życie Włocławka i Okolicy" 1927, nr 3, c. 12.

${ }^{35}$ Ibid., c. 13. 
декоративными колоннами, сложными карнизами и т. п. становится только трафаретной ширмой, которая должна прикрыть творческое бессилие архитектора, который разве что может еще кое-где понравится провинциальным невежам и дилетантам (Szlachetność proporcji obyć się może całkowicie bez sakramentalnych 'porządków' architektury klasycznej, a szczere ujawnienie materiału i solidność wykonania daje efekty istotniejsze od gipsowych cacek [...] Architektura weszła w posiadanie nowych i celowych możności. Niedostrzeganie ich i uparte szafowanie dekoracyjnymi kolumnami, skomplikowanymi gzymsami etc. staje się tylko szablonowym parawanem dla twórczego ubóstwa architekta, zdolnego jeszcze tu i ówdzie zaimponować prowincjonalnym ignorantom i laikom)»» ${ }^{36}$.

Теоретические исследования архитектор сочетает с практической работой. Он создает проекты ворот и павильонов для Выставки сельского хозяйства и промышленности, участвует в перестройке артиллерийских казарм, строит дома (на улицах Крулевецкой 8 и Торговой 12), двухэтажное здание больницы и амбулатории Еврейского Товарищества помощи бедным (Towarzustwo Wspomagania Biednych Żydów), возводит здание женской католической Гимназии имени Янины Стейнбокувны во Влоцлавке, перестраивает виллы и строит водные лечебницы (бани) в курортном городке Чехочинек (Ciechocinek). Оригинальную комбинацию готических (остроконечные завершения ниш) и барочных мотивов содержит созданный им в 1926 году проект жилого дома для Влоцлавка (ныне в Музее архитектуры во Вроцлаве).

Созданный им (около 1927 года) проект сельского костела (ныне в Музее архитектуры во Вроцлаве) свидетельствует о стремлении к продолжению тех традиций сакральной, прежде всего барочной архитектуры, которые ассоциировались с прекрасным, гордым и величественным прошлом страны.

${ }^{36}$ Ibid., c. 13-14. 


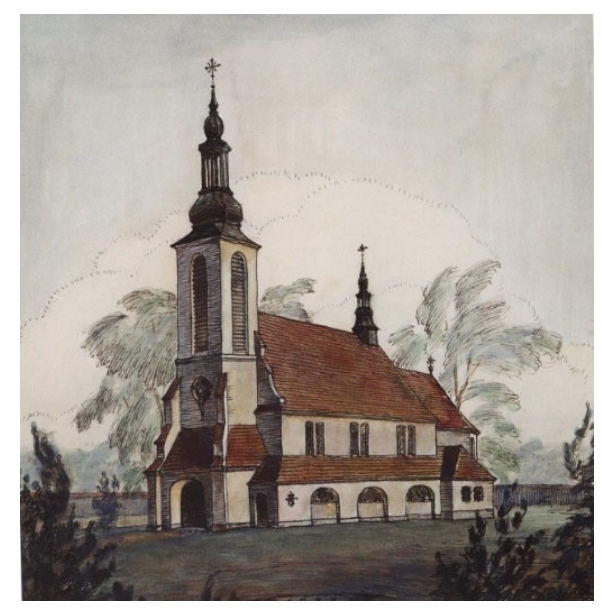

\section{Илл. 2. Стефан Нарембский, Проект деревенского костела, 1927}

Наиболее значительным, завершенным и сохранившимся до наших дней произведением Нарембского влоцлавского периода является здание Городского Музея (ныне Музея Земли Куявской) во Влоцлавке. Разработанный в 1926 году проект был реализован в последующие годы, уже после отъезда Нарембского из Влоцлавка (строительство завершено в 1930 году).

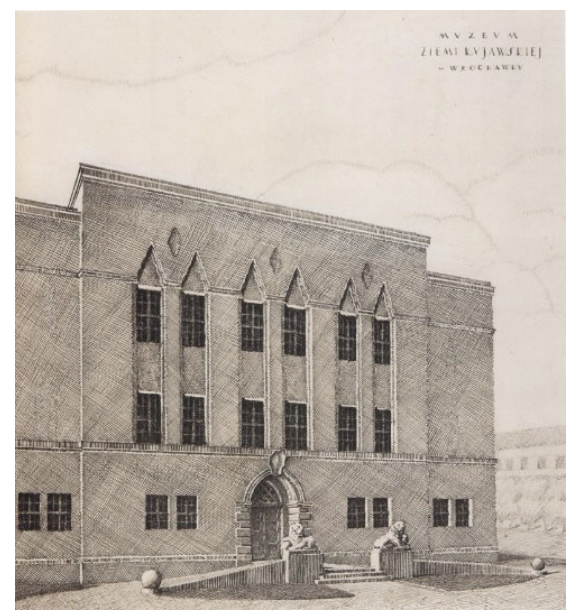

Илл. 3. Стефан Наребский, Проект городского Музея (Музея Земли Куявской) для Влоцлавка, эскиз 1926 


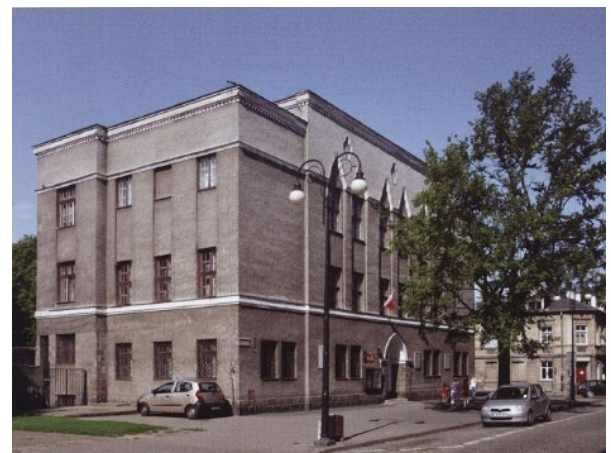

\section{Илл. 4. Стефан Нарембский, Музей Земли Куявской во Влоцлавке, 1926-1930}

Этот проект, по мнению зодчего и историка польской архитектуры Ежи Фрыча, «можно считать образцом здания регионального музея» ${ }^{37}$. Цельный, компактный объем трехэтажного здания архитектор расчленяет с каждой стороны на три горизонтальные полосы: 1) мощный цоколь с прямоугольными окнами (сдвоенными со стороны главного фасада), 2) второй и третий этажи, объединенные пилястрами «большого ордера», 3) высокий аттик со слегка выступающим карнизом. Спокойный ритм горизонтальных и вертикальных членений, строгая симметрия, преобладание форм прямоугольных очертаний соответствуют задачам «функциональной» архитектуры - функционализму как одному из модернистских направлений в зодчестве 1920-х годов, слегка окрашенному в данном случае реминисценциями готики. Немногочисленные, но весьма эффектные вкрапления и детали (высокая арка портала, стрельчатые остроконечные ниши над окнами третьего этажа на фасадной стороне здания, врезающиеся в аттик) напоминают готические и ренессансные мотивы, «привязывающие» новую постройку к архитектурному пейзажу города. Строительство Музея сопровождалось широким оповещением общественности о характере, задачах, особенностях новой архитектуры и намерениях художника ${ }^{38}$.

${ }^{37}$ J. Frycz, Stefan Narębski (1892 - 1966), architekt, profesor UMK [в книге:] Toruńscy twórcy nauki i kultury (1945 - 1958), red. M. Biskup, A. Giziński, Warszawa - Poznań - Torun 1989, c. 235-240; здесь с. 236.

${ }^{38}$ Budowa gmachu Muzeum Ziemi Kujawskiej, „Życie Włocławka i Okolicy” 1928 , nr 11-12, c. $15-18$. 
В 1927 году Нарембский был назначен на должность городского архитектора (главного архитектора) Влоцлавка, но работал на этом посту недолго, ибо в 1928 году выиграл конкурс на более престижную должность главного архитектора Вильнюса. Интеллигенция Влоцлавка с большим сожалением расставалась с Нарембским. «...Отъезд господина инженера Нарембского - истинная утрата для нашего города, - писала газета „Экспресс Куявский”. - Господин инженер Нарембский за время своего пребывания во Влоцлавке проявил себя как необычайно активный, деятельный человек, живо интересующийся всеми явлениями культурной жизни и плодотворно сотрудничающий во многих местных культурных институтах (...wyjazd p. inż. Narębskiego jest istotną stratą dla miasta. P. inż Narębski w ciągu swego pobytu we Włocławku dał się poznać jako człowiek niezwykle czynny, interesujący się wszelkimi przejawami życia kulturalnego i pracujący pożytecznie w wielu tutejszych instytucjach kulturalnych)» ${ }^{39}$.

39 Pożegnanie p. inż. Narębskiego przez inteligencja włocławska, „Ekspress Kujawski” 1928, nr 58 (dnia 8 marca), c. 6. Цитировано по источнику: Stefan Narębski. 1892-1966. Architekt, konserwator, profesor [Katalog wystawy], autor katalogu Michał Pszczółkowski, Toruń 2017, c. 7. 


\section{6. НАРЕМБСКИЙ В ПОЛЬСКОМ ВИЛЬНЮСЕ (1928-1939): СВЯЗИ С УНИВЕРСИТЕТОМ СТЕФАНА БАТОРИЯ И ХУДОЖЕСТВЕННОЕ ПОЛЕ ТВОРЧЕСТВА}

В Вильнюсе Нарембский сразу же активно включается в культурную и общественную жизнь города, принимает участие в работе различных комиссий (в частности, Воеводской Комиссии по вопросам консервации памятников - Okręgowa Komisja Konserwatorska), просветительских организаций, творческих союзов: Объединения архитекторов Польской Республики / Stowarzyszenie Architektów Rzeczypospolitej Polskiej - SARP (в течение ряда лет занимал пост Председателя этого Объединения); Вильнюсского товарищества художников / Wileńskie Towarzystwo Artystów Plastyków - WTAP; Coвета вильнюсских художественных объединений / Rada Wileńskich Zrzeszeń Artystycznych - RWZA / Erwuza; созданного в 1933 году клуба литераторов и художников "Smorgonia"; сотрудничает в работе секции истории искусства вильнюсского Товарищества любителей наук. Он принимает участие в подготовке (будучи членом Оргкомитета), а затем в работе Съезда деятелей культуры (Zjazd Działaczy Kulturalnych), который состоялся в Вильнюсе в начале ноября 1934 года ${ }^{40}$.

Особого внимания заслуживают его отношения с Отделением Изобразительных Искусств Университета Стефана Батория (ОИИ УСБ). Формально он не был ни воспитанником, ни выпускником этой школы, и в документах УСБ, в перечне имен преподавателей его имя появляется сравнительно поздно - впервые в 1935 году. Этой датой отмечено появление Нарембского среди преподавателей ОИИ УСБ, круг которых расширялся на протяжении 1920-30-х годов, в каталоге организованной в Торуни весной 1996 года выставки «Художественное образование в Вильнюсе и его традиции»: новые назначения получили Ян Боровский (1924), Людомир Слендзинский (1925), Тимон Несёловский (1928), Бронислав Ямонтт и Ежи Хоппен (1931), Стефан Нарембский (1935), после смерти Болеслава Балзукевича (1935) руководителем кафедры скульптуры стал Генрих Куна

40 Об этом съезде и его значении подробнее см.: St. Lorentz, Album wileńskie, Warszawa 1986, c. 176-177. 
$(1936)^{41}$. В биографической справке о жизни и творчестве Нарембского, включенной в каталог выставки «Вильнюсская художественная среда 1919-1945», показанной в Ольштине летом 1989 года, указано, что он, еще не будучи штатным сотрудником УСБ, начинает читать здесь лекции в 1935 году, в 1937 году занимает должность «чрезвычайного профессора» ${ }^{42}$ в мастерской проектирования и декорации интерьеров, а профессорское звание получает уже после переезда в 1945 году в Польшу ${ }^{43}$. Ежи Фрыч также указывает на то, что Нарембский начинает читать лекции по консервации памятников и архитектурному проектированию на ОИИ УСБ в 1935 году, и вспоминает еще о том, что параллельно он читает лекции по вопросам сельского строительства на Сельскохозяйственном факультете (отделении) УСБ ${ }^{44}$. Михал Пшчулковский публикует обнаруженный им в варшавском Архиве новейших дел интересный документ 1937 года - рекомендацию, отправленную на имя декана ОИИ УСБ Людомира Слендзинского за подписью крупнейшего представителя художественного дизайна в польском искусстве довоенного периода ректора Краковской Академии художеств Войцеха Ястшембовского (Wojciech Jastrzębowski), который характеризует Нарембского как выдающегося, обладающего сильным творческим потенциалом и любящего свое дело, свою профессию художника («wybitny, twórczy

${ }^{41}$ J. Poklewski, Wydział Sztuk Pięknych Uniwersytetu Stefana Batorego 19191939 [в книге:] Kształcenie artystyczne $w$ Wilnie i jego tradycje / Vilmiaus Meno mokykla ir jos tradicijos, red. katalogu J. Malinowski, M. Woźniak, R.Janonienè, Toruń 1996, c. 102.

$42 \mathrm{~B}$ европейской академической системе звание «чрезвычайного» (или «университетского») профессора (profesor nadzwyczajny) находится на более низкой ступени, чем «обычный» («полный») професcop (profesor zwyczajny, Full Professor).

43 Wileńskie środowisko artystyczne 1919-1945, malarstwo, grafika, rzeźba, rysunek, fotografia \{Katalog wystawy zorganizowanej w Galerii Sztuki Współczesnej w Olsztynie], autor wystawy K. Brakoniecki, [Olsztyn 1989], c. 74. Однако, судя по тому, что в этой справке даже место рождения Нарембского указано ошибочно («Вильнюс» вместо «Грозный»), можно предположить, что и другие биографические данные указаны здесь неточно.

${ }^{44}$ J. Frycz, Stefan Narębski (1892-1966), architekt, profesor UMK [в книге:] Toruńscy twórcy nauki i kultury (1945-1958), red. M. Biskup, A. Giziński, Warszawa - Poznań - Toruń 1989, с. 235-240; здесь с. 236. 
i rozmiłowany w swej pracy zawodowej artysta" $)^{45}$. По документам, coхранившимся в Личном деле С. Нарембского в Архиве УНК, звание «чрезвычайного» (университетского) профессора было присвоено ему 14 сентября 1937 года, звание «полного» профессора - 24 октября 1947 года (свидетельство о присвоении этого звания подписано главой государства - Болеславом Берутом).

У нас нет точных данных о том, в каком качестве пребывал Нарембский в Университете до 1935 года и кого из преподавателей УСБ старшего поколения можно считать его прямым учителем или косвенным наставником. Несомненно, однако, что вся его творческая жизнь в Вильнюсе начиная с 1928 года была постепенным приобщением к университетской культуре, к традициям ОИИ УСБ, прежде всего к школе консервации и реставрации памятников, а также к архитектурной школе и к школе архитектурного дизайна.

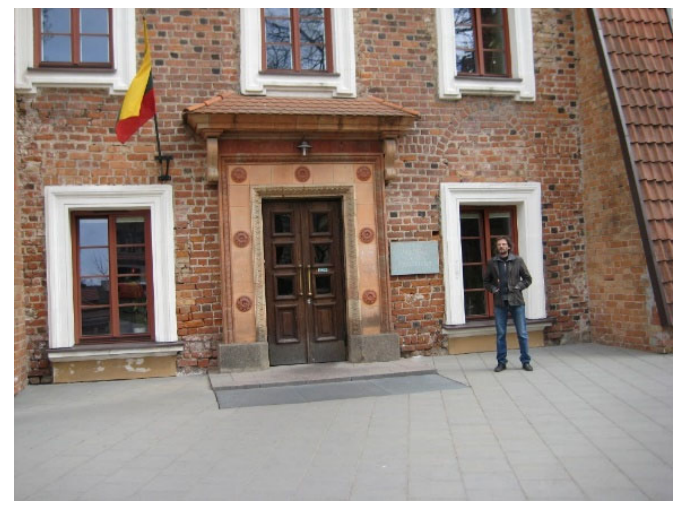

\section{Илл. 5. Здание бывщего Отделения изобразительных искусств Университета Стефана Батория на улице Св. Анны в Вильнюса (ныне Вильнюсская Академия художеств), современное состояние}

Надо знать, чем был для всех жителей Вильнюса возрожденный в 1919 году Университет, которому было присвоено имя национального героя - польского короля Стефана Батория, чтобы понять, что вне этого Университета полноценная жизнь городской интеллигенции была просто немыслима, и те семь лет, которые пролегают между возвращением Нарембского в город своего детства

${ }^{45}$ Цитировано по источнику: Stefan Narębski. 1892-1966. Architekt, konserwator, profesor [Katalog wystawy], autor katalogu Michał Pszczółkowski, Toruń 2017, c. 7. 
(1928) и началом его преподавательской работы в УСБ на кафедре проектирования и декорации интерьеров (1935), никак не были годами жизни «вне» Университета, или без постоянных контактов с этим Университетом. Как свидетельствовали об этом многие исследователи, а также люди, жившие в Вильнюсе в 1920-30-х годах и причастные к его культуре, «все виленчане считали университет своим, и это чувство личной принадлежности каждого жителя Вильнюса к университету [...] было чистой правдой, которую трудно объяснить тем, кто там не жил (Owo powszechne uznanie przez wilnian Uniwersytetu za swój, za osobiście własny trudno wytłumaczyć ludziom nie tutejszym [...] A była to najzwyczajniejsza prawda)» ${ }^{46}$. В своей речи в Стокгольме при вручении ему Нобелевской премии Чеслав Милош говорил об этом: «Удостоенным благословением судьбы считал себя каждый, кому выпало жить в Вильнюсе в школьные или университетские годы - в этом изумительном городе барочной итальянской архитектуры, перенесенной в северные леса, в городе, где каждый камень несет на себе отпечаток истории... Только теперь я понимаю, как много проникло в меня сквозь толстые стены старого университета (Jest błogosławieństwem, jeżeli ktoś otrzymał od losu takie miasto studiów szkolnych i uniwersyteckich, jakim było Wilno, miasto dziwaczne, barokowej i włoskiej architektury przeniesionej w północne lasy, i historii utrwalonej w każdym kamieniu... Dopiero teraz rozumiem, jak duże przenikało we mnie przez mury tego uniwersytetu) "47. „С детства помню мрачные коридоры здания, в котором размещалась первая вильнюсская гимназия, где запрещено было даже говорить по-польски. И вот победа - Университет возрожден! ( $Z$ dzieciństwa pamiętałem mroczne korytarze gmachu, w którym mieściła się wówczas pierwaja wileskaja gimnazja, gdzie mówić po polsku nie było wolno. I oto - zwycięstwo: odnowienie uniwersytetu!)", - вспоминал ксёндз Валериан Мейштович ${ }^{48}$. А вот слова из письма к матери декана факультета гуманитарных наук возрожденного университета Людвика Яновского: «Если бы ты знала, как я счастлив! Я вернулся в мой любимый Вильнюс! И такое чудесное открывается передо мной поле для работы, для творческой работы! (Gdybyś wiedziała,

46 A. Gołubiew, Wychowawca [в книге:] Unoszeni historia, Kraków 1971, c. 284; цитировано по источнику: Cz. Zgorzelski, Alma Mater Vilnensis, „Ethos” 1988, nr 1, с. 72-88, здесь с. 73.

${ }^{47}$ Cz. Miłosz, Zaczynajac od moich ulic, Paryż 1985, c. 352.

${ }^{48}$ Ks. W. Meysztowicz, Gawędy o czasach i ludziach, Londyn 1983, c. 223. 
jakim szczęśliwym! Do ukochanego Wilna wróciłem! Takie cudowne mam pole do pracy, takiej twórczej pracy!) ${ }^{\text {«4 }}$. Вероятно, Нарембский чувствовал ту же гордость и радость, резкий контраст между «чужими» школами своего вильнюсского детства и «своим» университетом, который для него теперь был открыт.

В Вильнюсе художник осознает необходимость освоения новых методологических подходов к задачам архитектурного проектирования, расширения знаний, связанных с польским (особенным на «Восточных Кресах») художественным наследием и современным архитектурным процессом, которые не могла дать ему ни российская архитектурная школа 1911-1916 годов, ни молодая Варшавская Политехническая школа начала 1920-х годов.

Вильнюсская школа архитектурно-художественного проектирования, сложившаяся в стенах УСБ, пользовалась авторитетом и признанием в национальном и даже более широком - европейском масштабе. Во главе этой школы с начала 1920-х годов стоял архитектор Юлюш Клос (Juliusz Kłos), который сам так писал о ее значении: «Воскресшее заново вместе с Университетом в 1919 году Отделение изобразительных искусств готовит кадры молодых архитекторов, которые, будучи воспитаны в традициях польской художественной культуры, глубоко проникнуты светом красоты вильнюсской архитектуры и способны на ее образцах учиться и постигать тайны своей достойной профессии, должны стать в ближайшем будущем верными последователями и обновителями той великой архитектурной идеи, которую - в бесконечной цепи столетий - излучает душа польского Вильнюса (Wskrzeszony wraz z Uniwersytetem w r. 1919 Wydział Sztuk Pięknych przygotowuje kadry młodych architektów, którzy wychowani w tradycji sztuki polskiej, prześwietleni pięknością architektury wileńskiej i na niej uczący się tajemnie swego szczytnego zawodu, stać się powinni w najbliższej przyszłości wiernymi wyznawcami i powołanymi odnowicielami tej wielkiej idei architektonicznej, którą w nieskończonym łańcuchu wieków wypromienia dusza polskiego Wilna)" ${ }^{\text {"50 }}$.

С 1921 года на кафедре архитектуры, благодаря стараниям профессора Ю. Клоса, преподавательскую работу начинают архитек-

${ }^{49}$ Цитировано по источнику: W. Horoszkieczówna, Promienisty. Prof. Ludwik Janowski, „Alma Mater Vilnensis” 1922, nr 1, c. 42.

${ }^{50}$ J. Kłos Wilno, Przewodnik krajoznawczy, wyd. I, Wilno 1923, c. 99-100. 
торы Людвик Соколовский (Ludwik Sokołowski) и Оттон Краснопольский (Otton Krasnopolski) ${ }^{51}$. Правда, формально кафедра архитектуры в УСБ по нелепому и совершенно ничем не обоснованному решению Министерства просвещения была ликвидирована в 1926-27 учебном году ${ }^{52}$, но на самом деле это была не вполне состоявшаяся ликвидация: Ю. Клос продолжал работать в Университете вплоть до своей трагической гибели в 1933 году, Л. Соколовский - вплоть до своей смерти в 1938 году, а следовательно, учащиеся имели возможность продолжать архитектурное образование и после закрытия кафедры. В 1922 году в УСБ была создана под руководством профессора Ежи Ремера кафедра истории искусства. Ежи Ремер, исполнявший в то время также обязанности консерватора памятников искусства Вильнюсского воеводства (konserwator okręgowy), ввел в программу занятий этой кафедры, наряду с историей искусства, также основы консервации и реставрации произведений искусства $^{53}$. Таким образом формировался своеобразный перекресток, а точнее узел теснейшего переплетения друг с другом разных специальностей (архитектуры, архитектурного дизайна, консервации и реставрации памятников, истории искусства с ее особой отраслью изучения памятников / zabytkoznawstwa), в котором Нарембский, как художник, мог в полной мере реализовать свои интересы и способности. По сути, он и был одновременно архитектором, дизайнером, реставратором памятников и историком искусства, и сложилось это единство в лоне традиций УСБ. После отъезда профессора Ремера из Вильнюса в 1928 году ${ }^{54}$ на Отделении изобразительных искусств продолжались занятия по консервации и реставрации памятников; эти занятия, как пишет Юзеф Поклевский, проводили - в хронологической последовательности друг за другом вплоть до закрытия УСБ в 1939 году - доктор Станислав Лоренц (Lorentz), инженер Ян Боровский (Borowski), профессор Стефан Нарембский и доктор Пётр Богдзевич (Bohdziewicz).

${ }^{51}$ J. Poklewski, Polskie Życie artystyczne $w$ międzywojennym Wilnie, Toruń 1994, c. 266.

${ }^{52}$ Ibid, c. 267.

${ }^{53} \mathrm{Ibid}$, c. 266.

${ }^{54}$ Archiwum UMK, K 8/221, Jerzy Remer, Akta Osobowe. В 1930-37 годах Ремер был профессором Варшавского университета и вновь появился в кругу бывших виленчан, ставших репатриантами из Литвы в Польшу, в 1945 году в Торуни, где стал профессором Университета Николая Коперника. 
В Университете Стефана Батория Нарембский работал вплоть до закрытия литовскими властями этого университета 15 декабря 1939 года ${ }^{55}$. В декабре 1939 года в качестве представителя профессуры закрытого УСБ Нарембский официально участвовал в актах передачи имущества ОИИ УСБ литовским властям, приступавшим к организации на базе этого отделения новой литовской - Высшей Свободной Художественной школы (будущей Вильнюсской Академии художеств $)^{56}$. В отличие от своих коллег по ОИИ УСБ - художников Тимона Несёловского, Александра Штурмана и Ежи Хоппена - Нарембский не воспользовался в 1940 году возможностью продолжить педагогическую работу в новой Вильнюсской Академии художеств (Высшей Свободной Художественной школе), созданной на базе ОИИ УСБ решением Правительства Литовской Республики ${ }^{57}$ буквально накануне аннексии Литвы Советским Союзом и начавшей свой первый учебный год (1 октября 1940 года) уже в «Литовской ССР»; его преподавательская деятельность прекратилась в 1939 году и возобновилась только после репатриации в Польшу (1945), определяя одну из важнейших нитей преемственной связи между вильнюсским Университетом Стефана Батория и новым Университетом Николая Коперника в Торуни.

В течение десяти лет (с 1 января 1928 до 31 декабря 1937 года) Нарембский работает в вильнюсской Городской Управе в качестве «городского архитектора».

Творчество Нарембского в Вильнюсе развивается на фоне процессов модернизации городской архитектуры и становится органичной частью этих процессов, направленных на качественное преображение провинциального города «воеводского» (областного) масштаба в центр современной европейской урбанистики. «После аннексии (присоединения к Польше) Вильнюс получил статус воеводского центра, - пишет об этом Раса Бутвилайте. - Здесь, как и в других городах Польши, в 1919-1939 годах возникли многочисленные институты местного самоуправления, банковского

55 О драматических обстоятельствах закрытия этого университета см.: Likwidacja Uniwersytetu Stefana Batorego przez władze litewskie w grudniu 1939 roku. Dokumenty i materialy, Zebrał i wstępem opatrzył P. Łossowski, Warszawa 1991.

${ }^{56}$ Архив литературы и искусства Литвы - Lietuvos Literatūros ir meno archivas / LLMA, F. (Фонд) 63, ар. (опись) 1, b. (единица хранения. Дело) 8, 11. (листы) 36, 37, 39, 41, 44.

57 Dailés mokyklu statymas, "Vyriausybès Žinios» nr 706 (25.05. 1940), eil. [ordinal number] 5439. 
дела, науки, образования, здравоохранения, социального обеспечения, культуры, системы коммуникации и транспорта. Разнообразие функциональных задач способствовало широкому разнообразию архитектурных форм и появлению в этот период гетерогенной архитектуры. Принимаемые решения были направлены на бережную охрану исторической зоны старого города, на обновление его памятников, придание им новой жизни, а также на новое строительство в духе модернизованного традиционализма и даже чистого модернизма (особенно за чертой старого города, в новом Вильнюсе), что должно было создать контр-баланс по отношению к архитектурному облику города царских времен и определить главные вехи урбанистического развития и характер архитектурных пейзажей во многих городских зонах (Vilnius was annexed and acquired the voivodship centre status. In 1919-1939, like in many other Polish cities, new institutions of local government, banking, science and education, health, social insurance, communication, transport and culture were established. The variety of functional needs led to the wide variety of architectural forms of that period and the appearance of heterogenous architecture. Institutional decisions aimed to prudently preserve of the Old Town of Vilnius, to revitalize its monuments, and the new buildings of modernized traditionalism and pure modernism just outside the old city (especially in the New Town) counterbalanced the Tharist architectural image of the city as well as formed new guidelines for urban development and architectural landscape in many urban areas)»> ${ }^{58}$. В этой атмосфере жил и работал Нарембский.

Одним из первых и по-своему знаменательных индивидуальных проектов Нарембского, реализованным в Вильнюсе в 1930-31 годах, были «школы на Антакальнисе». Трехэтажные здания-«близнецы», предназначенные для средних школ (одно - для мужской гимназии имени генерала Л. Желиговского / Lucjan Żeligowski), второе - для женской гимназии имени поэта В. Сирокомли / Władysław Syrokomla), соединены друг с другом, как два крыла единого ансамбля, общим гимнастическим залом. В отдельных деталях, особенно в рисунке порталов на торцовой стороне, очерчен-

58 R. Butvilaite, Public buildings in the Interwar Vilnius [в книге:] Międzynarodowa konferencja naukowa "Miédzywojenne Wilno: kształty sztuki $i$ architektury w latach 1919-1939" / International Conference "Interrwar Vilnius: Dhapes of Art and Architecture in 1919-1939”, Vilnius 2019, c. 30. 
ных характерной «разорванной» аркой, ощутима перекличка с мотивами барокко ${ }^{59}$, но в общем решении ансамбля элементы «историзма» и стилизации явно отходят на второй план, уступая место функциональному началу. Выстроенные торжественными рядами высокие прямоугольные окна прекрасно вписаны в строгие прямоугольные очертания боковых и главных фасадов и обеспечивают свободный доступ широких потоков света в интерьеры. Особое внимание уделил художник конструктивному пространственному решению и оформлению помещений, предназначенных для проведения совместных культурных и праздничных предприятий мужской и женской гимназий: логика, ясность, рациональность всей архитектурной среды становятся здесь основой для создания той атмосферы, в которой человек чувствует себя свободным, внутренне распрямленным, не угнетенным.

Есть нечто символическое в том, что первыми сооружениями Нарембского в Вильнюсе являются школа (средняя школа для мальчиков и девочек в том возрасте, в каком он сам учился в этом городе не так уж много лет тому назад, но совсем в иную историческую эпоху) и его собственный жилой дом, сооруженный для своей семьи и семьи своего брата в Монтвилловском переулке (проект 1929 года был реализован в 1930 году). Эти сооружения как бы становятся воплощенным в архитектурную реальность ответом художника на вопрос, тревоживший его еще в детстве: как должен жить поляк в своем родном городе (уже не принужденный видеть из своего окна истуканы палачей, охраняемые жандармами), как должна учиться молодежь - не в «чужой», а в «своей», польской школе, с достоинством носящей имена выдающихся деятелей национальной армии и национальной культуры, в школе, принадлежащей к миру католической духовности (зал, предназначенный для литургии в объединенных гимназиях, выделенный во внешнем объеме здания маленькой башенкой звонницы / sygnaturką, был в этом контексте важной частью архитектурного замысла). В оформлении собственного дома Нарембский использовал мотивы вильнюсского барокко (что особенно заметно в формах порталов), а в интерьерах, как пишет об этом Юзеф Поклевский, «с глубоким знанием дела и совершенством выработал во всех малейших деталях

59 По мнению Юзефа Поклевского,, проектируя эти порталы, Нарембский ориентировался на образцы роскошных порталов расположенного недалеко от места данного сооружения дворца Сапегов (J. Poklewski, Polskie życie artystyczne w międzywojennym Wilnie, Toruń 1994, c. 176). 
все компоненты дизайна: металлические обрамления, деревянные панели, бордюры, камины, лампы, люстры и особенно мебель, которая была предметом его многолетних научных исследований (...z głębokim znawstwem i perfekcją opracował w najdrobniejszych szczegółach wszystkie elementy wystroju: okucia, boazerie, posadzki, kominki. lampy, żyrandole, a zwłaszcza stanowiące przedmiot wieloletnich badań i studiów - meble)» ${ }^{60}$. В этой работе в полной мере ощутима характерная для всего творчества Нарембского забота о выявлении естественной красоты и благородства различных материалов.

Диапазон сооружений, которые Нарембский проектирует и надзор над строительством которых осуществляет, выполняя обязанности городского архитектора, исполняя частные заказы, а также реализуя собственные мечты и планы (заказчиками не оплачиваемые), оказывается очень широк. Это жилые дома, школы, здания административного, социального, культурно-просветительского назначения, костелы, выставочные залы, торговые павильоны, промышленные объекты, надгробные мемориалы, памятники. По его проектам строятся такие сооружения, связанные с новыми задачами развития экономики, торговли, межрегиональных и международных связей Вильнюса с другими польскими и европейскими центрами, как, например, торговый павильон Вильнюса на одной из площадок открытого здесь «Северного Рынка» (1929). Он создает проект дома для рабочих на улице Деревницкой, проект городского трансформатора (около 1930), проект оздоровительного центра (1939). В 1934 году вместе с архитектором-реставратором Станиславом Лоренцом и художником Людомиром Сленлзинским Нарембский совершает перестройку помещений, выделенных Союзом литераторов для Совета вильнюсских художественных объединений (Rada Wileńskich Zrzeszeń Artystycznych - RWZA / Erwuza) ${ }^{61}$.

Начало Второй мировой войны помешало реализации разработанного в 1938-39 годах проекта Нарембского - здания Сельскохозяйственного Отделения УСБ. Здание было задумано как сочетание двух массивных четырехэтажных кубов, соединенных ризалитом, украшенным высокими коринфскими пилястрами.

Не ограничиваясь строительством в самом Вильнюсе, он создает проекты сооружений для провинции - малых городов и селений

${ }^{60} \mathrm{~J}$. Poklewski, Polskie życie artystyczne $w$ międzywojennym Wiknie, Toruń 1994, c. 176

${ }^{61}$ St. Lorentz, Album wileńskie, Warszawa 1986, c. 128. 
Вильнюсского края и «Восточных Кресов», в частности, проект дворянской усадьбы под Беняконями / Bieniakoni (1929), сооружает дворец в Больчениках (Bolcieniki) Лидского уезда (Lidzkiego powiatu), проектирует концертный зал в Барановичах (до 1939 года).

Значительное место в творчестве Нарембского вильнюсского периода занимает сакральное зодчество. По его проекту строится деревянный костел в Креве (1934-1936), выдержанный в традициях народного творчества, по отношению к которым Нарембский проявляет бережность и чуткость; сооружаются костелы в Колонии Виленьской и в Полукне, часовня над гробом епископа Бандурского в ансамбле вильнюсского Кафедрального собора.

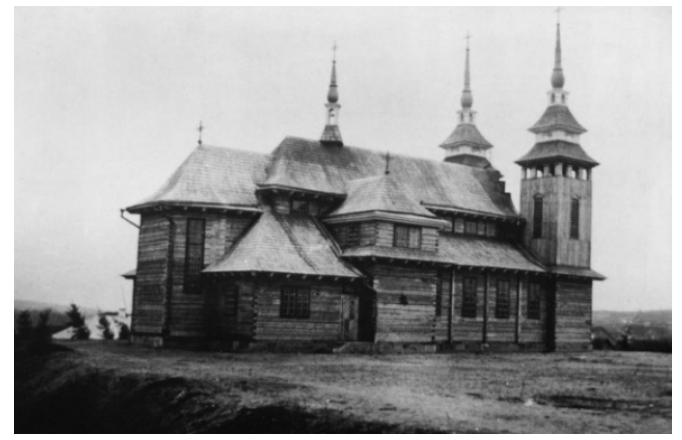

\section{Илл. 6. Стефан Нарембский, Деревянный костел в Креве, 1934}

Живой интерес проявлял он к дизайну интерьеров, к принципам художественного оформления внутреннего пространства общественных зданий и жилищ.

По его проекту была осуществлена масштабная перестройка бывшего «доходного дома» на Кафедральной площади в дворецрезиденцию вильнюсского архиепископа (работы начались в 1932 и завершились в 1935 году). Внешний облик дворца архиепископа - трехэтажного здания, увенчанного аттиком, скупо, но выразительно украшенном рельефной скульптурой, - свидетельствует о стремлении художника развивать исторические традиции светской (дворцовой) архитектуры Вильнюсского края, в основе которых - память о ренессансных палаццо (влияния итальянской архитектурной школы), представления о великолепии дворцов местных магнатов и вместе с тем о суровой неприступности этих зданий, хранящих отпечаток крепостной архитектуры. Цокольный этаж дворца акцентирован мощным рустом; высокие, узкие окна 
второго этажа обрамлены стрельчатыми арками; пилястры, простирающие на всю высоту второго и третьего этажа, окружают здание, словно могучий панцирь. Конечно, это - не настоящая готика, не Ренессанс, не барокко, но память об исторических стилях, господствовавших в прошлом в архитектуре Вильнюса, живет в этом сооружении середины 1930-х годов.

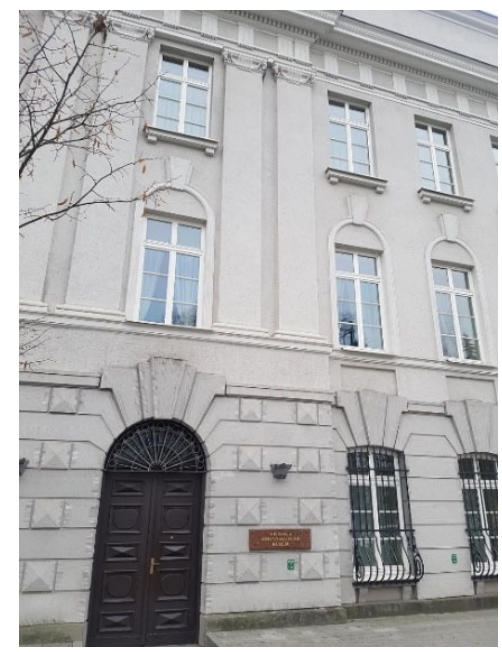

Илл. 7. Стефан Нарембский, Дворец архиепископа в Вильнюсе, реконструкция 1932-1935, современное состояние

Более современно выглядят его просторные интерьеры - салоны, украшенные ионическими колоннами, столовая с высоким камином и декоративным фризом, протянувшимся широкой полосой по всему периметру стен.

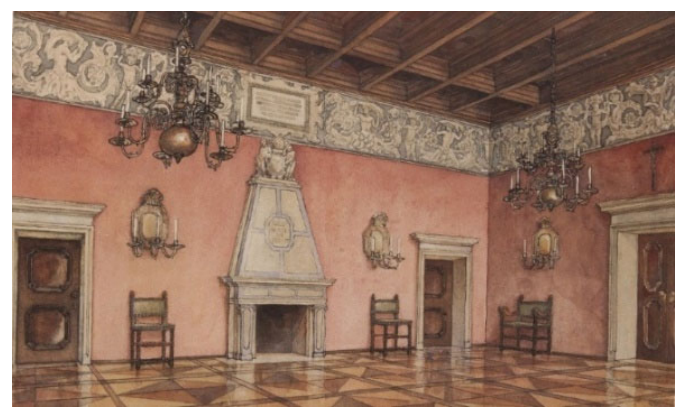

Илл. 8. Стефан Нарембский, Интерьер дворца-резиденции архиепископа в Вильнюсе, каминный зал, после 1932 
Отзвуки барокко и классицизма, реминисценции модерна (югендштиля), мотивы современного конструктивизма в изломанном геометрическом рисунке некоторых предметов - все это сложно смешивается и переплетается в атмосфере сверкающих интерьеров, которые никак нельзя назвать старомодными. Репрезентативность новой резиденции архиепископа вполне соответствует тем идеалам культурного обновления, модернизации, которые формировались внутри католической церкви, искавшей в эти годы новый язык духовного общения со своей паствой, с «городом и миром». Особой задачей, увлекавшей Нарембского при создании этих интерьеров, было выявление эстетической ценности материалов и совершенства всех формирующих интерьер компонентов - светильников, мебели, паркетных инкрустаций. Это совершенство каждой детали и целого ансамбля - побеждало ту эклектику, которая возникала бы на основе «архитектурного цитирования» многих и разнообразных источников, если бы это «цитирование» не было столь творческим и безупречным в техническом исполнении.

Одним из любимых предметов художественного проектирования в творчестве Нарембского был камин. По мере технического прогресса, коснувшегося, в частности, системы отопления вильнюсских зданий административного, общественного назначения и жилых домов, он постепенно терял свое прямое функциональное назначение, но оказывался тем более значимым как символ, как связующее звено между современным обликом интерьера и памятью о ярком очаге, согревающем и освещающем родной дом. В некоторых проектах Нарембского камин приобретает величественный, монументальный характер, воспринимается как своеобразный алтарь и даже как самостоятельное архитектурное сооружение храмового типа. Примером может служить созданный им в 1937 году проект камина для зала сената Университета Стефана Батория ${ }^{62}$. Исходя из традиций античной храмовой архитектуры, из строгой ордерной системы, Нарембский сочетает эту систему с великолепием барокко, размещая над аркой каминного отверстия, на высокой стенке трапециевидных очертаний монументальное живописное панно с изображением короля Стефана Батория на белом коне в обрамлении пышного картуша, увенчанного короной.

${ }^{62}$ Работа была частью более масштабного проекта реконструкции «Белого зала» и других интерьеров здания Университета Стефана Батория; над этим проектом Нарембский работал в конце 1930-х годов. 


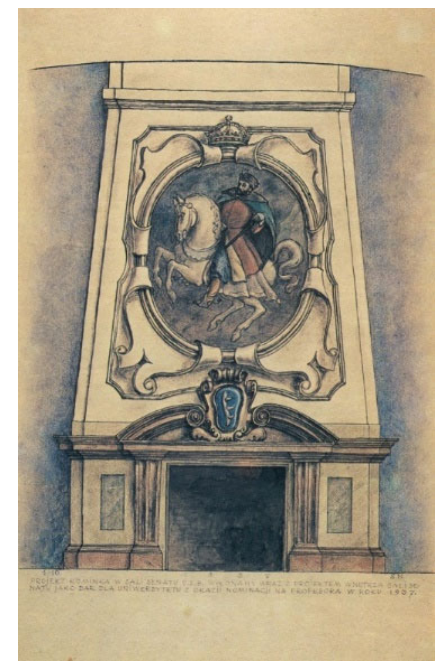

\section{Илл. 9. Стефан Нарембский, Проект камина для зала Сената Университета Стефана Батория, 1937}

В замыслах Нарембского, в занятиях, которые он ведет со студентами УСБ, в его практической работе значительное место занимают проекты, связанные с консервацией и реставрацией памятников.

Он участвует в консервация руин замка Гедиминаса ${ }^{63}$, а с 1938 года, после отъезда из Вильнюса архитектора-консерватора Ксаверия Пивоцкого (Ksawery Piwocki), руководит всем комплексом этих работ.

Широкий фронт работ развернулся в Вильнюсе в связи с проектом реставрации и перестройки здания городской Ратуши - шедевра архитектуры классицизма, созданного Лауринасом Гуцявичюсом (Laurynas Gucevičius). Театр, размещавшийся в этом здании до революции, был закрыт в 1924 году. Было принято решение восстановить здание, предназначив его для торжественных заседаний городского совета, а также для постоянной музейной экспозиции ${ }^{64}$. Нарембский обратился к задаче реставрации и перестройки Ратуши сразу же, как только стал главным архитектором

${ }^{63}$ См. об этом: E. Budreika, Gedimino kalno Pilies Vilniuje Vakarinio bokšto rekonstrukcijos, „Metraštis“ 1958, c. 6.

${ }^{64}$ Первый проект преобразования Ратуши в Городской музей был разработан Юлюшем Клосом (Juliusz Kłos) еще в 1924 году, однако финансовый кризис помешал тогда его осуществлению. См. об этом: R. Butvilaite, E. Povilaitytė-Leliugienè, Vilniaus rotušes pertvarkymas bei prytaikymas 40 
Вильнюса, - в 1928 году. Разработанный им проект был завершен в 1937 году ${ }^{65}$. Проект предполагал сооружение новой лестницы, которая ведет с улицы к главному порталу, и размещение на боковых фасадах широких оконных проемов в традициях классицизма. Лестничный марш получал продолжение в интерьере, для которого предназначалась великолепная мраморная лестница с балюстрадой, ведущая на второй этаж. Этот этаж должен был быть украшен колоннадой, восстановленной по оригинальному проекту Гуцявичюса. Тщательно была продумана и разработана в деталях система естественного и электрического освещения, отопления, водоснабжения и проветривания помещений в соответствии с требованиями и техническими возможностями того времени. Большое внимание в разработке этого проекта Нарембский уделял выбору материалов, их эстетической выразительности: для покрытия пола был выбран гранит, для лестницы, ведущей в большой колонный зал, - серый мрамор ${ }^{66}$. Разработанный Нарембским проект предполагал активное включение в интерьеры произведений современного изобразительного искусства (над монументально-декоративными композициями работали художники Людомир Слендзинский, Ежи Хоппен, Казимир Квятковский). К сожалению, далеко не в полной мере этот проект успели и смогли осуществить, но Ратуша была спасена от разрушения, начавшегося уже в период ее эксплуатации в качестве театра, и еще долгие годы служила жителям и гостям Вильнюса в качестве музея: сначала здесь размещался Музей города Вильнюса, после войны - «Художественный музей Литовской ССР», ныне это снова городская ратуша в соответствии с исходным назначением сооружения.

Vilniaus miesto muziejui [в книге:] (Ne)matomas Vilnius: tarpukario dailes ir architektūros pavidalai. Parodos katalogas. Vytauto Kašiulio dailès muziejus, 2018 m. liepos 12 d. - rugsejo 16 d. / (In)visible Vilnius: Shapes of interwar Art and Architecture. Exhibition catalogue. Vytautas Kasiulis Art Museum 12 Juky - 13 September 2018, red. A. Andriulytė, R. Burvilaitė, I. Mažeikienė, Vilnius 2018, c. 16.

65 Эскизы, созданные рукой Нарембского, сохранились в папке Проект перестройки здания Ратуши в Вильнюсе / Projekt przebudowy gmachu Ratusza $w$ Wilnie в Художественном музее Литвы (Lietuvos Dailès Muziejus / Lithuania,s Art Museum) в Вильнюсе.

${ }^{66}$ Stefan Narębski. Katalog wystawy, Toruń 1967, c. 10. 


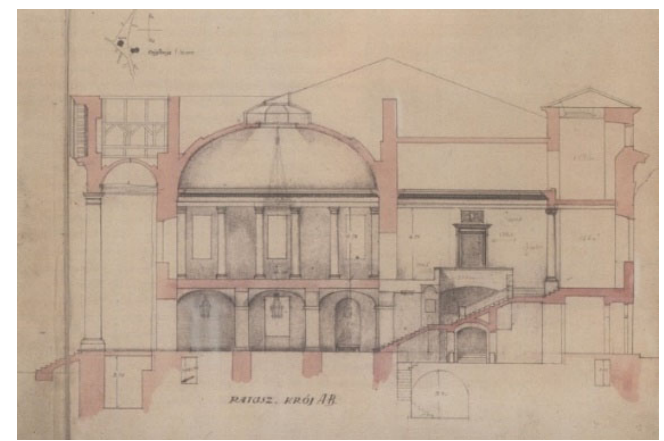

\section{Илл. 10. Стефан Нарембский, Проект реконструкции Городской Ратуши в Вильнюсе, 1937}

Важным моментом деятельности Нарембского в качестве консерватора и реставратора памятников искусства было участие в работе созданной в 1931 году комиссии, ответственной за обновление Остробрамской часовни (часовни Св. Аушры) и реставрацию иконы Остробрамской Богоматери, которая была высшей сакральной ценностью католического Вильнюса ${ }^{67}$. Задаче консервации интерьера Остробрамской часовни в Вильнюсе современники придавали большое общественное и научное значение ${ }^{68}$, а после падения коммунистического режима как в Польше, так и в Литве появились исследования, раскрывающие художественную ценность этого ансамбля, сбереженного польскими реставраторами междувоенного периода и исследованного историками искусства вильнюсской школы ${ }^{69}$.

${ }^{67}$ Альге Андрюлите в своей монографии, посвященной творчеству Фердинанда Рушчица, приводит восстановленный ею на основе архивных материалов полный состав этот комиссии: ксёндз С. Завадский (S. Zawadzki) - председатель, епископ К. Михалкевич (K. Michałkiewicz), прелат Л. Жебровский (L. Żebrowski), декан Отделения Изобразительных искусств УСБ Ф. Рушчиц (F. Ruszczyc), профессора Ю. Клос (J. Kłos), M. Мореловский (M. Morelowski), Л. Слендзинский (L. Slendziński), художник-реставратор C. Лоренц (St. Lorentz), архитекторы-инженеры C. Нарембский (S. Narębski), Я. Боровский (Jan Borowski) (A. Andriulytė, Ferdynandas Ruszczycas: Civis Vilnensiss Sum, Vilnius 2018, c. 249).

${ }^{68}$ Cм. об этом: St. Lorentz, Konserwacja wnętrza kościoła Ostrobramskiego w Wilnie, „Ochrona Zabytków”, cz. I, c. 212-216.

69 См.: M. Kałamajska-Saeed, Ostra Brama w Wilnie, Warszawa 1990 (докторская диссертация); V. Drèma, St. Lorentz, Laiškai / Listy, Vilnius 1998, c. $132-135$. 
Непосредственное участие принимал Нарембский в работах, связанных с археологическим открытием в подземной крипте вильнюсского Кафедрального собора (осенью 1931 года) «королевских гробниц»: останков короля Александра, Эльжбеты и Барбары Радвилайте (Elżbieta i Barbara Radvilaitė), урны с сердцем короля Владислава IV. Это открытие взволновало весь Вильнюс и широким эхом откликнулось в Польше. Почти вся творческая элита художественного Вильнюса, практически вся профессура ОИИ УСБ была причастна к развернувшимся в связи с этим открытием дискуссиям, к зарисовкам открывшихся сокровищ, к проектированию нового мемориала. Фердинанд Рушчиц в своем Дневнике вспоминает о присутствии Нарембского в этой крипте ${ }^{70}$. По проекту Нарембского в 1933 году были сооружены деревянные гробы с прибитыми к ним серебряными таблицами, занявшие позднее место в завершенном мавзолее. В 1937 году Нарембский принял участие в конкурсе на проект этого мавзолея ${ }^{71}$.

Архитектурное проектирование и строительную практику Нарембский сочетает с историческими исследованиями в области истории архитектуры и урбанистики и с теоретическим обоснованием важнейших проектов, в частности, связанных с реконструкцией центра Вильнюса - Кафедральной площади, на которую он предлагал вывести новые городские артерии и магистрали ${ }^{72}$. Серьезным историческим исследованием развития планировки и градостроительной системы Вильнюса стал опубликованный в 1935 году труд Нарембского Очерк урбанистического развития Вильнюса и план его застройки 1817 года $a^{73}$. В 1935 году он начал свой труд

${ }^{70}$ Ferdynand Ruszczyc, Dziennik, t. 2, W Wilnie 1919-1932, Warszawa 1996, c. 601 .

71 Первую премию в этом конкурсе получил, однако, архитектор Станислав Буковский. См. об этом: S. Wicher, Wileński dorobek architekta Stanistawa Bukowskiego - przyczynek do dalszych badan / Achievenebts of the architect Stanislaw Bukowski in Vilnius - a contribution to the futher research [w:] Międzynarodowa konferencja naukowa "Miédzywojenne Wilno: ksztatty sztuki i architektury w latach 1919-1939” / International Conference "Interrwar Vilnius: Dhapes of Art and Architecture in 1919-1939", Vilnius 2019, c. 34-36.

72 Этот проект получил обоснование в статье Нарембского Архитектурные возможности Вильнюса (S. Narębski, Możliwości architektoniczne Wilna, „Środy Literackie” 1936, nr 3, s. 1-6), однако не был реализован.

${ }^{73} \mathrm{~S}$. Narębski, Zarys rozwoju urbanistycznego Wilna i plan zabudowania z roku 1817 [в книге:] Prace $i$ materiały Sekcji Historii Sztuki Wileńskiego Towarzystwa Przyjaciół Nauk, t. 2, Wilno 1935, c. 339-345. 
Заметки о вильнюсском мебельном производстве (Uwagi o meblarstwie wileńskim), иллюстрируя его собственными зарисовками (работа осталась неизданной в полном объеме, однако значительная ее часть стала достоянием польской научной общественности, высоко оценившей этот труд, причем в значительной мере эта высокая оценка приходится уже на послевоенный период $\left.{ }^{74}\right)$. Всю свою творческую жизнь Нарембский был не только архитекторпрактик, но также историк и теоретик архитектуры.

Многогранность творческих интересов Нарембского отмечали все его современники. «Стефан Нарембский любил рисовать, особенно создавать карикатуры, - вспоминает профессор Станислав Лоренц, живший и работавший в Вильнюсе в 1927-1935 годах, Его интересовали не только памятники и архитектурное творчество, но также история мебельного ремесла в Вильнюсе первой половины XIX века (Lubił rysować też zwłaszcza karykatury, Stefan Narębski, który interesował się nie tylko architekturą zabytkową i twórczością architektoniczną, ale też meblarstwem wileńskim z pierwszej połowy XIX wieku)» ${ }^{75}$.

Многие архитектурные проекты и постройки Нарембского изначально были рассчитаны на синтез с монументально-декоративной скульптурой или естественно становились ареной такого синтеза по мере того, как интерьеры «заполнялись» скульптурой. Авторами этих скульптурных произведений были вильнюсские ваятели, которых Нарембский хорошо знал по совместной работе в Университете Стефана Батория, и с которыми ему еще предстояло совместно работать в Университете Николая Коперника в Торуни. Так, в часовне Св. Петра, созданной по проекту Нарембского в ансамбле Кафедрального собора, видное место в алтаре заняла композиция Pacnяmuе (krucyfiks) Тадеуша Годзишевского ${ }^{76}$, а позднее был сооружен надгробный памятник каплану польских Легионов епископу Владиславу Бандурскому (Władysław Bandurski) работы Станислава

74 См.: I. Grzeluk, Stefana Narębskiego „Uwagi o meblarstwie wileńskim”, „Kwartalnik Historii Kultury Materialnej” 1996, nr 4, c. 415-429.

${ }_{75}$ St. Lorentz, Album wileńskie, Warszawa 1986, c. 44.

${ }^{76}$ Из биографии Тадеуша Годзишевского известно, что заказ на скульптурное изваяние (в дереве) распятого Христа для часовни в вильнюсском Кафедральном соборе он получил в 1935 году, работа над этим монументальным резным Распятием двухметровой высоты продолжалась два года (См.: Rzeźba Tadeusza Godziszewskiego. Katalog wystawy, wstęp: St. Lorentz, opracowanie noty biograficznej: A. Męczyńska, Toruń 1977, c. 6). 
Горно-Поплавского ${ }^{77}$. Фигура епископа, поднятая на высоком постаменте, находилась в нише, обрамленной полукруглой аркой и фланкированной двумя пилястрами; все архитектурные детали были выдержаны в духе строгого классицизма в идеальном соответствии с общим обликом вильнюсского Кафедрального собора.

Достойную роль сыграл Нарембский в той драматической истории, которая была связана с сооружением в Вильнюсе памятника Адаму Мицкевичу по проекту скульптора Генриха Куны (точнее, с крахом этого не осуществленного проекта). Вместе с другими художниками - профессорами УСБ - он встал на защиту этого проекта, подвергавшегося вульгарным нападкам со стороны настроенной националистически и консервативно части вильнюсской общественности. Он защищал его не только словом ${ }^{78}$, но и делом, разработав архитектурный проект установки памятника на улице Мицкевича ${ }^{79}$.

Будучи человеком широкого круга интересов и способностей, Нарембский работал в разных видах и жанрах искусства. На выставках экспонировались его акварели и рисунки, главным образом, портреты близких людей ${ }^{80}$. Не доходили до выставок, но пользовались большой популярностью в художественной среде острые и выразительные карикатуры, которые он рисовал на университетских профессоров и представителей городской элиты.

В его личной жизни большое значение имели рождение и воспитание дочери Барбары ${ }^{81}$. От отца она унаследовала многогран-

${ }^{77}$ Cм. об этом: J. Kłos, Wilno, Przewodnik krajoznawczy, wyd. II, Wilno 1929, c. 128; J. Poklewski, Polskie życie artystyczne $w$ międzywojennym Wilnie, Toruń 1994, с. 141-143, илл. 59.

${ }^{78} \mathrm{~B}$ своей статье о том, какое место должен занять этот памятник в городском ансамбле, Нарембский резко критиковал попытки вытеснить его на окраину и утверждал, что памятник должен стоять в той исторической зоне, которая является «Вильнюсом Мицкевича» (S. Narębski, O wtaściwa sytuację pomnika Mickiewicza, „Kurier Wileński” 1937, 28. V.).

79 Рисунок Нарембского - эскизный проект постановки памятника на улице Мицкевича - опубликован в книге: J. Poklewski, Polskie życie artystyczne w międzywojennym Wilnie, Toruń 1994, c. 301.

${ }^{80}$ На выставке «Вильнюсская художественная среда 1919-1945» были показаны Портрет Баси (1928, рисунок карандашом и мелом), Портрет жены (рисунок сангиной), Тетка Юстысечка (Justysieczka), 1943, акварель (Wileńskie środowisko artystyczne 1919-1945, malarstwo, grafika, rzeźba, rysunek, fotografia \{Katalog wystawy zorganizowanej w Galerii Sztuki Współczesnej w Olsztynie], [Olsztyn 1989], c. 74).

${ }^{81}$ Барбара Нарембская-Дембская-Козловская (Barbara Narębska-DębskaKozłowska) родилась во Влоцлавке в 1921 г., в 1938-39 гг. училась на ОИИ 
ность творческих интересов и в художественную жизнь послевоенной Польши вошла как мастер графики (цветной гравюры на дереве, литографии, композиций в технике «мягкий лак»), педагог, журналист, художественный критик, историк искусства ${ }^{82}$, поэт. Ее лирические стихи, написанные в Вильнюсе в июне 1939 года (когда она была еще 18-тилетней девушкой), поразительным образом выражают ту нежную любовь к Вильнюсу и то пронзительное чувство тревоги и предчувствие расставания с ним, которые, наверно, были общими у отца и дочери:

«Czerwcowy wieczór pachnący i świeży,

Cichy zmrok Wilna, miłego miasta.

Wyszłam na balkon, z katedralnej wieży

Zegar wydzwania czas. Jedenasta.

Śpi miłe miasto, śpi Wilno kochane,

Śpi domów odbiciem w wód Wilii głębinie.

Śpi miłe miasto legendą owiane,

Legendą o wilku i o Gedyminie... ${ }^{83}$

В символическом измерении это был, действительно, одиннадцатый час наступающей ночи: до катастрофы 1 сентября 1939 года оставалось всего два месяца.

УСБ, в 1940-41 и в 1944 гг. - в Вильнюсской Академии Художеств, в 1945-49 гг. - на ОИИ УНК в Торуни. См.: A. Rissmann, Twórczość Barbary Narębskiej-Dębskiej (1921-2000). Urodzona dla architektury wilnianka z Kujaw [в книге:] Barbara Narębska-Dębska. 1920-2000. Grafika [Katalog], red. A. Rissmann, Toruń 2010, c. 5-9.

82 Много сил Барбара Нарембская приложила для того, чтобы сохранить творческое наследие своего отца, классифицировать и описать его работы, составить библиографию появившихся в печати отзывов, откликов на его творчество, воспоминаний о нем (см.: B. Narębska-Dębska, Bibliografia prac prof. Stefana Narębskiego, „Biuletyn Historii Sztuki” 1967, nr 2, c. 225-226).

${ }^{83}$ B. Narębska, Wilno [в книге:] Wileńskie środowisko artystyczne 1919-1945, malarstwo, grafika, rzeźba, rysunek, fotografia [Katalog wystawy zorganizowanej w Galerii Sztuki Współczesnej w Olsztynie], [Olsztyn 1989], c. 7. Подстрочный перевод: «Июньский вечер ароматный и свежий, тихие сумерки Вильнюса, милого города. Я вышла на балкон; с кафедральной башни доносится бой часов. Одиннадцать. Спи, милый город, спи, любимый Вильнюс. Спи отражением своих домов в водах Вилийи. Спи, город, овеянный волшебной легендой о волке и князе Гедиминасе...». 


\section{7. В ЛИТВЕ «ПОД КРАСНОЙ ЗВЕЗДОЙ» (1940-1941)}

В 1940-41 годах (в «советском» Вильнюсе) Нарембский работает архитектором государственной архитектурно-проектной организации «Промпроект» (Promprojekt), которая должна была решать задачи промышленного строительства и укрепления военных объектов в оккупированной советскими войсками Литве.

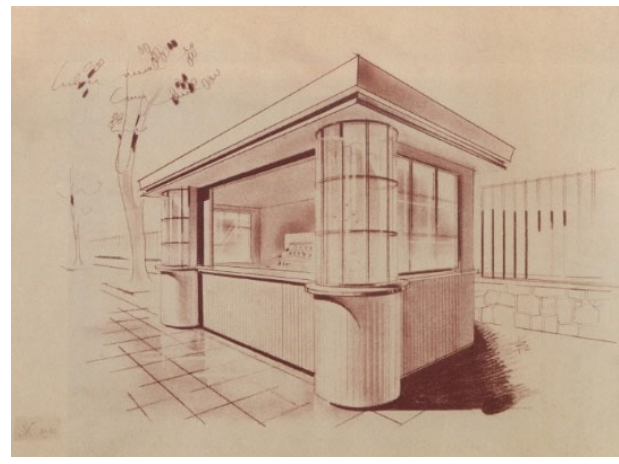

\section{Илл. 11. Стефан Нарембский, Проект киоска для Вильнюса, начало 1941}

К сожалению, в нашем распоряжении мало материалов, свидетельствующих о том, что делал Нарембский в Вильнюсе в первый год советской оккупации (что проектировал он как архитектор, что рисовал как график и карикатурист). Мы не знаем ни одной статьи, написанной им в это время; ничего не знаем о том, как лично он принял те «великие перемены», которые кардинально меняли (ломали / преображали) судьбу его города и его страны. Предположить можно разные варианты, поскольку часть вильнюсской польской интеллигенции встретила «советскую власть» протестом, активным или пассивным сопротивлением, бойкотом, презрением и ненавистью, в то время как другая часть (может быть, не меньшая) сотрудничала с этой новой властью, и даже не только потому, что вынуждена была сотрудничать, зарабатывая свой хлеб насущный, но также и потому, что поверила этой власти, оказалась в плену иллюзий «социалистического преобразования» мира, построения «светлого будущего». 
Интереснейшая выставка, показанная в Каунасе в 2010-2011 годах, под названием «Под красной звездой. Искусство Литвы 19401941 годов» ${ }^{84}$ со всей наглядностью продемонстрировала процесс падения этого искусства, поставленного на службу коммунистической агитации и пропаганды, практически во всех его видах и жанpax - от оформления городских площадей, улиц, массовых «манифестаций трудящихся», общественных интерьеров до сатирической журнальной и газетной, книжной графики, плакатов, портретной живописи, монументальной скульптуры. Значительная часть показанной на этой выставке художественной продукции остается анонимной: организаторы выставки не всегда находили, а возможно, и не слишком охотно искали имена авторов всех этих сооружений и проектов, создаваемых под светом «красной звезды», но совершенно очевидно, что среди этих авторов были не только «чужие», сидевшие в московских кабинетах и мастерских, но и «свои», в частности, вильнюсские художники разных национальностей - литовцы, поляки, евреи, белорусы, русские. Был среди них, по всей видимости, и Нарембский, а также его ученики по кафедре художественного проектирования интерьеров УСБ. Из автобиографии Нарембского, написанной им в 1950 году, известно, что он создал «проект интерьеров для зала заседаний Совета Народных Комиссаров Литовской ССР» и даже считал этот проект одной из «важнейших» своих работ ${ }^{85}$. Даже не видя этого проекта (он не сохранился), мы можем представить себе, что не обошлось здесь ни без портретов «вождей», ни без той самой советской символики, которая определяла атмосферу жизни «под красной звездой». Ответственность (или во сяком случае часть ответственности) за то падение морали и вкуса, которым сопровождался расцвет искусства коммунистической агитации и пропаганды в едва только сформированной «Литовской ССР», несомненно, ложится на всю довоенную творческую интеллигенцию, в частности, также на профессуру бывшего ОИИ УСБ. В такой же мере и гордость за общее национальное (и литовцев, и поляков, и всех других жителей

${ }^{84}$ См.: Po raudonaja žvaigžde. Lietuvos daile 1940-1941 m., Parodos knyga, sudarytoja G. Jankevičiūte, Vilnius, 2011.

${ }^{85}$ Она фигурирует в собственноручно составленном им «Списке важнейших произведений» (Wykaz ważniejszych prac) в его Личном деле, хранящемся в Архиве Университета Николая Коперника. 
Литвы) неповиновение, непримирение, сопротивление советскому режиму, выражавшееся в разных формах, могут по достоинству разделить со своими соотечественниками и согражданами самых разных социальных слоев и профессий польские художники Вильнюса, вступившего во Вторую мировую войну. Тот факт, что в своих послевоенных автобиографиях и воспоминаниях Нарембский ничего не пишет о его собственном участии в этом сопротивлении, вполне объясним той обстановкой, которая складывалась в ПНР: вряд ли профессор контролируемого государственными и партийными органами власти Университета Николая Коперника мог открыто в чем-то подобном признаться. В целом, однако, ни его творчество, ни его личность неотделимы от того драматического перелома, который переживает Вильнюс в 1940-41 годах.

Вероятно, к первому году существования в Литве советской власти относятся архитектурные проекты Нарембского, связанные с новым строительством в Лентварисе (Lentvaris / Landwarów). Судя по тому, что одной из таких работ был проект металлургического комбината, советская власть в 1940-41 году вынашивала планы превращения этого маленького городка, расположенного в семи километрах от древней исторической столицы Литвы - Тракайского замка - и имевшего свое романтическое историческое прошлое (битва с крестоносцами в 1394 году), в новый промышленный центр, связанный с Вильнюсом веткой железной дороги. Об успехах этого промышленного строительства судить трудно (до сих пор Лентварис остается тихим, маленьким городком, главной индустриальной достопримечательностью которого является фабрика ковров-килимов, открытая в бывшем дворце графа Тышкевича в 1957 году). Однако сам по себе чертеж (проект металлургического комбината) свидетельствует о прогрессивном мышлении художника-архитектора, стремившегося «очеловечить» промышленную архитектуру, придать ей рациональный характер и обеспечить экологическую чистоту окружения. Здание металлургического комбината на этом чертеже имеет сходство с типами тех просветительских учреждений (музей, школа), которые занимали главное место в творчестве Нарембского довоенного периода. 


\section{8. В ЛИТВЕ ПОД ФАШИСТСКОЙ СВАСТИКОЙ (1941-1944)}

Вскоре после вторжения немецких оккупантов в Вильнюс в июне 1941 года Нарембский, как и большинство других сотрудников польской национальности, был уволен из «Промпроекта» и, имея на своем иждивении троих детей (кроме старшей дочери, у него были сын Войцех 1925 года рождения и сын Юлюш 1927 года рождения), жену и мать жены, остался без постоянного заработка. В его жизни наступило тяжелейшее время.

В годы фашистской оккупации Вильнюса (1941-1944) Нарембский принимает непосредственное участие в антифашистском движении сопротивления. Это движение не ограничивалось «тайным обучением» польских студентов, исключенных из высших учебных заведений Литвы, в частности, из Вильнюсской Академии художеств, и лишенных возможности учиться легально, но включало другие, более активные формы борьбы с оккупантами. Одним из конспиративных центров этого движения был антикварный отдел комиссионного магазина братьев Ярослава и Пшемыслава Нечецких (Jarosława \& Przemysława Niecieckich) в Вильнюсе, в котором Нарембский числился консультантом по вопросам антиквариата. Задачей этого центра была скупка ценных произведений искусства, которые надо было спрятать от оккупантов и предотвратить их вывоз в Германию. Нарембский в своих Записках вспоминает случай, когда ему пришлось прятать ценнейшую картину, возможно, кисти Каналетто (летом 1944 года ее решили перепрятать, перенесли в частный дом, но этот дом сожгли немцы, отступавшие из Вильнюса).

В тяжелейших условиях он продолжает свои историкоискусствоведческие исследования, в 1942 году пишет статью Об одной группе памятников архитектуры рококо в Вильнюсе (O pewnej grupie zabytków architektury rokokowej w Wilnie); сохранился только ее машинописный вариант, о котором вспоминает в своем очерке Ежи Фрыч ${ }^{86}$.

Чрезвычайно интересной страницей в истории искусства является сооружение и последующая роспись интерьеров церкви Благовещения в Лентварисе. Несмотря на то, что в последнее время об

${ }^{86}$ J. Frycz, Stefan Narębski (1892-1966), architekt, profesor UMK [в книге:] Toruńscy twórcy nauki i kultury (1945-1958), red. Marian Biskup, Andrzej Giziński, Warszawa - Poznań - Toruń 1989, с. 235-240; здесь с. 238. 
этом ансамбле уже немало написано ${ }^{87}$ (в отличие от «советских времен», когда ни в каких публикациях он даже не упоминался), роль Нарембского в создании этого ансамбля остается до сих пор недостаточно ясной. Сам он в перечне своих основных работ, составленном уже после войны, скромно упоминает о том, что разработал проект оформления интерьеров этого костела. Сооружением этого костела (надзором за ходом строительных работ) он занимался еще в довоенный период, начиная с 1933 года. Тогда здесь возобновилось начатое еще в 1910 году и оставшееся незавершенным в связи с войной и революцией строительство костела по проекту итальянского зодчего Орсино Борджи (Orsino Borgi). Нарембский бережно отнесся к проекту своего предшественника, но все же внес в него существенные коррективы, связанные, в частности, с сооружением в его ансамбле семейной часовни графов Тышкевичей, с завершением башни и с изменением формы капителей колонн. Интереснейший художественный ансамбль сложился здесь в 19421943 годах, когда уволенный из Вильнюсской Академии художеств художник Ежи Хоппен (Jurgys Hopenas) вместе со своими учениками (в этой группе работали Леонард Торвирт / Leonardas Torwirtas, Она (Анна) Рудокайте-Торвиртене / Ona (Anna) RudokaitèTorvirtienė, Игнотас Багдонавичюс / Ignotas Bagdonavičius, Эдвардас Синкевичюс / Edvardas Sinkievičius, Леонардас Янушкявичюс / Leonardas Januškevičius) ${ }^{88}$ создали в интерьерах этого костела монументальные сграффито, энкаустики и фрески на евангельские сюжеты. Эти работы велись нелегально, втайне от оккупационных властей, и сами по себе были и вызовом этим властям, и продолжением местных, католических культурных традиций, что имело особое значение в мобилизации патриотического духа польского и литовского населения оккупированной нацистами Литвы. Католическая церковь играла при этом исключительную, позитивную, благородную роль, предоставляя польским художникам небольшой, но достойный и спасительный для их жизни заработок (средства на строительство и обновление костелов собирались прихожанами и

${ }^{87}$ Cм.: M. Maksymuk, Kościół pod wezwaniem Zwiastowania Najświetniejszej Marii Panny w Landwarowie pod Wilnem, Paznań 2000; G. Jankevičiūtè, Bažnytine daile naciu okupoutoje Lietuvoje, Vilnius 2011, c. 193-232; G. Jankevičiūtè, Lantvario bażnyčia ir jos dekoras, Vilnius 2012.

${ }^{88}$ В документах военных лет все имена польских художников приводятся в литовской транскрипции в соответствии с теми паспортами, которые были выданы жителям Вильнюсского края после его присоединения к Литве в октябре 1939 года. 
дополнялись из казны церковных организаций) и возможность творческой работы. Если в Лентварисе авторы росписей еще не выходили за границы традиционной иконографии, то следующая работа того же авторского коллектива, а именно роспись церкви в Перлойе (Perloja - городок в 10 км от Варены, в 89 км от Вильнюса), на этот раз частично легализованная (настоятель костела заключил договор с вильнюсским отделением каунасской строительной фирмы «Строительство / Statyba») и законченная к 1 декабря 1943 года ${ }^{89}$, включала среди росписей по сухой штукатурке (циклов fresco-secco), заполнивших нефы и плафоны костела, такие сюжеты (геральдические мотивы литовской государственной символики и даже текст национального гимна «Литва - наша Отчизна / Lietuva Tevinè mūsų“ на слова Винцаса Кудирки), что их патриотическое звучание, объективно направленное против оккупационного режима в Литве, не оставляло сомнений. О том, советовался ли Ежи Хоппен, руководивший работами по росписи костелов в Лентварисе и в Перлойе, с Нарембским по вопросам выбора сюжетов и их размещения в интерьере, у нас нет данных, однако, несомненно, что вся история, связанная с работой группы польских монументалистов и дизайнеров в Лентварисе и Перлойе, является частью творческой биографии Нарембского.

Самый драматический период жизни Нарембского в условиях оккупации приходится на 1943 год, когда он был арестован, находился в гестаповской тюрьме в Лукишках, а затем в концлагере («исправительно-трудовом лагере») в Правенишках (Prawieniszki) вблизи Каунаса. Сам художник подробно рассказывает в своих $3 a$ писках об обстоятельствах этого ареста и обо всем, что довелось ему пережить.

Нарембский стал одним из тех ста польских заложников - жителей Вильнюса, которых схватило гестапо, действующее в данном случае в сговоре с литовской военной организацией «самообороны» («Sauguma»), в ответ на совершенный одним из подпольных отделений Армии Крайовой акт ликвидации литовского коллаборациониста по фамилии Падаба. Арестованных, среди которых находились видные представители польской вильнюсской интеллигенции, ночь продержали в бывшем здании городского суда; на рассвете первую группу заложников (10 человек) вывели из

${ }^{89}$ Cм. об этом: D. Vasiliūnienė, Senu tapyba Perlojos bažničioje, „Menotyra“ 2004, nr 3, c. 36. 
тюрьмы. «Освобожденные» и остававшиеся в заключении радовались за них и надеялись, что их отпускают на волю, но их всех расстреляли. Среди расстрелянных оказались и профессора УСБ, которых Нарембский хорошо знал; одного из них просил сообщить своей жене о том, где он находится.

За оставшимися в заключении заложниками вскоре приехали грузовики и повезли их в сторону Панеряйского форта, который был местом массовых казней в оккупированной фашистами Литве. Арестованные были уверены, что из везут на расстрел, и вздохнули с облегчением только когда транспортная колонна миновала Панеряй (Понары). Их привезли в «трудовой лагерь» Правенишки. Среди привезенных в лагерь заложников были известные профессора УСБ, в том числе декан бывшего Отделения Изобразительных искусств профессор Людомир Слендзинский.

Заключенные в лагере были обречены на тяжелый физический труд. «Бараки были страшным клоповником, - вспоминает Нарембский, - так что спать было невозможно (Baraki były okropnie zapluskwione, tak że spać było niepodobne)» ${ }^{90}$. «Укладывая дубовые доски, - рассказывает он далее, - совершенно сорвал себе ноготь с пальца. Не освободило это меня от работы. От работы освобождали только тех больных, у которых температура была выше 39 градусов (Podczas układania szczep dębowych całkowicie zdarłam sobie paznokieć z palcu. Nie zwolniło się to z pracy. Zwolnić się można było tylko przy gorączce większej jak 39 st.)"'91. Нарембский вспоминает многие случаи проявления солидарности и взаимопомощи между заключенными лагеря, в том числе между поляками, литовцами, русскими; сам он старался опекать 16-летнего русского мальчика, жившего с ним в одном бараке.

Бои за Вильнюс, развернувшиеся в начале июля 1944 года, Нарембский пережил дома, скрываясь в подвале. В городе было небезопасно, немцы, отступавшие из города, стреляли в поляков, уничтожали всех, кто скрывался. «Специальные команды, занимавшиеся уничтожением мирных жителей, - пишет Нарембский, - сходили с ума, поджигали дом за домом [...] Времена были очень тяжелые (Vernichtungkomando szalało, palili dom po domu [...] Czasy były b. ciężkie)",92.

${ }^{90}$ Archiwum UMK w Toruniu, K-9/360, Akta osobowe. Narębski Stefan, 1945 1962, Pamiętniki, c. 36.

${ }^{91}$ Ibid, c. 37.

${ }^{92}$ Ibid, c. 38. 


\section{9. В «ОСВОБОЖДЕННОМ» ВИЛЬНЮСЕ (1944-1945): ИЗ ТЮРЫМЫ ГЕСТАПОВСКОЙ В ТЮРЬМУ НКВД}

Не менее тяжелыми оказались для художника и времена восстановления в Вильнюсе советской власти.

Здесь он пережил то, о чем не принято было вспоминать в публикациях о его творчестве, появлявшихся в ПНР, и даже в не предназначенных для широкого доступа анкетах и биографиях художника, хранившихся в Отделе кадров Университета Николая Коперника.

Восстановим эту страшную страницу жизни Нарембского по его позднейшим воспоминаниям, никогда не публиковавшимся.

«14 декабря 1944 года, - рассказывает он, - я выбрался из дома, чтобы посетить бывшего заместителя городского старосты полковника Гижыцкого, который, как и многие в годы оккупации, занимался частной торговлей, чтобы купить бритву для бритья. Пришел к нему и попал в засаду. Там нас долго держали, пока не пришел офицер НКВД, который начал сортировать задержанных. Многих выпустили, но мне явно помешал тот факт, что во время оккупации я был заложником у немцев и литовцев, но меня почему-то из лагеря отпустили. Я снова оказался в тюрьме в Лукишках в здании бывшего суда. Меня держали в подвале. Однажды послали чистить грязь во дворе (хорошее занятие для профессора). За стеной я слышал голос нашего ректора [ректора бывшего УСБ] Эйренкройца, который скандировал свою фамилию. Из тюрьмы он уже не вышел, и я был последним из «своих», кто слышал его голос. Затем меня держали в «тюрьме № 1», в Лукишках. Забрали у меня обручальное кольцо без квитанции, будто бы это - не золото. Условия содержания в тюрьме были ужасны. В одиночных камерах, без какой-либо мебели, на цементном полу сидело порою по 20 человек. Камеры не отапливались, но в такой тесноте не было холодно. Мучили вши. Очень редко позволяли помыться. Вся тюрьма шумела, как улей, заполненный поляками. Среди арестованных было много патриотически настроенной молодежи. Люди пели партизанские песни. Люди голодали, кормили бедно - хлеб и «суп» с блестками от «свиной тушёнки». 
Следователь вызывал меня на допросы. Хотел выудить из меня как можно больше сведений. Всем обычно предлагали сотрудничать со следствием, коснулось это и меня. Некоторые арестованные рассказывали, что их били. Меня эта чаша миновала, но допросы были долгие и очень тяжелые. Выкручивался, как мог; наконец, решил коротко и категорично отказаться от сотрудничества. 'Жалко мне вас и вашу семью', - сказал следователь и сообщил, что меня вывезут. Я был в отчаянии, однако искал выход. Заметил, что в камерах начали появляться женщины-врачи. Смертность в тюрьме была очень высокая; видимо, поэтому начальство решило обратить внимание на состояние здоровья заключенных. Я вскоре обнаружил, что во всем этом царит страшный балаган, путают имена. После того, как мне пригрозили тем, что меня вывезут, уже видно было, что готовится этап. Свидетельствовали об этом шум, движение в коридорах; узников собирали в огромном помещении бывшей часовни. Стражники входили в камеры, зачитывали фамилии со своих списков и брали людей на этап. Я установил в камере порядок и запретил своим товарищам откликаться на неправильно произнесенные фамилии, что прежде многие поспешно делали, особенно крестьяне. В какой-то момент открылась дверь нашей камеры и стражник выкрикнул: «Наревский Степан». Я не шевельнулся, и другие предупрежденные мною товарищи не откликались на неправильно произнесенные фамилии. Стражники пошли дальше... В этот самый день этап заключенных ушел из тюрьмы, но без меня.

Когда врачи начали чаще заглядывать в камеры, все заключенные вокруг них толпились. Я снова установил порядок - очередность обращения к врачам. Однажды женщина-врач по собственной инициативе, заметив меня, сидящего в углу камеры, заросшего щетиной, опухшего от голода, обратилась ко мне на русском языке: «Что старик - без зубов?» (я нарочно вынул протезы) и записала мою фамилию. Это подтолкнуло меня к тому, чтобы прикинуться больным. Встал в очередь к этой врачихе. Вспомнил о том, что когда-то мой доктор обнаружил у меня недостаток в работе сердечных клапанов. Еще при немцах, от администрации «Арбайтсамт» я получил от доктора справку о том, что у меня больное сердце. Врачиха снова записала меня на прием. Вскоре вызвали меня ночью. В коридоре стояли, главным образом, старые люди. Нас завели в подвал и затолкнули в неосвещенные камеры, где уже находилось не- 
сколько заключенных. Утром дежурившая в коридоре полька обрадовала нас известием, что это камеры для «слабосильных», что отсюда не отправляют на этап и что скоро нас выпустят «праздновать пасху». И действительно, скоро нас начали освобождать [...] Меня освободили 16 апреля [1945 года] (14 grudnia 1944 r. wybrałem się do płk. Giżyckiego, starosty grodzkiego, który zajmował się, jak wielu podczas okupacji, handlem, kupić żyletkę do golenia. Trafiłem w kocioł. Trzymano [nas] dłuższy czas, po czym przyszedł oficer N.K.W.D. i sortował zdobycz. Wielu wypuszczono, mnie wyraźnie zaszkodziło to, że byłem u Niemców i Litwinów zakładnikiem i został wypuszczony. Siedziałem zrazu w gmachu sądów na placu Łukiskim w suterenie. Tam skierowano mnie raz do czyszczenia ustępu w podwórku (odpowiednie zajęcie dla profesora). Za ścianę posłyszałem głos naszego rektora [dawnego rektora USB] Ehrenkreutza skandującego swoje nazwisko. Ehrenkreutz z [więzienia] nie wrócił. Był to ostatni jego głos słyszany przez swego. Następnie siedziałem w 'tiurmie $\mathrm{Nr} 1$ na Łukiszkach'. Odebrano mi obrączkę dukatową, jako nie złotą - bez pokwitowania. Warunki były okropne. W celach pojedynczych na crmrncie bez mebli, [...] siedziało po 20 nieraz aresztowanych. Ogrzewanie nie funkcjonowało]...] Zrzadka można było zużyć łaźni. Całe więzienie huczało jak ul przepełnione Polakami. Masa młodzieży partyzanckiej. Słychać było wciąż partyzanckie piosenki. Karmiono głodowo; chleb i 'sup' w blaskach po 'swinoj tuszonkie'. Brał na spytki 'sledowatiel'. Chciał jak najwięcej wydobyć wiadomości. Proponowano zwykle współpracę. Spotkało to i mnie. Niektórzy mówili, że ich bito. Ja tego nie doznałem, ale 'doprosy' były długie i bardzo dokuczliwe. Wykręcałem się jak mogłem. Wreszcie postanowiłem krótko i kategorycznie odmówić. 'Żałko mnie was i waszej semji' rzekł i zapowiedział, że mnie wywiozą. [...] Wszakże szukałem wyjścia. Zauważyłem, że częściej zaczynają chodzić po celach lekarki. Była duża śmiertelność [...] Zauważyłem też, że jest nieludzki bałagan i żw przekręczają nazwiska. Po zagrożeniu, że mię wywiozą, niedługo szykował się transport. Wskazywał na to ogromny ruch na korytarzach i komasowanie więźniów w ogromnej byłej kaplicy. Po celach chodzili i z list dobierali do transportu. Zaprowadziłem w celi porządek i zabroniłem kręgować zniekształcone nazwiska, co wielu pochopnie robiło, zwłaszcza chłopi. Jakoż otworzono nasze cele i wywołano: Harewskij Stiepan. Ja nie zareagowałem, i inni uprzedzeni przeze mnie nie odezwali się. Poszli dalej... Tegoż dnia transport odszedł beze 
mnie. [...] Raz lekarka z własnej inicjatywy, ujrzawszy mnie siedzącego w końcowym rogu ceki, obrośniętego i spuchniętego z głodu, odezwała się: 'czto starik - bez zubow?" [...] i zapisała moje nazwisko. [...] Wywołano mnie w nocy. Na lorytarzu spotkałem przeważnie znajomych starszych ludzi. Zaprowadzili nas do suteren i powpychali do nieoświetlonych cel [...] Rano pełniąca służbę na korytarzu więźniarka Polka pocieszyła nas, informując, że tu są 'słabosilni' i z tych cel nie wywożą i że niedługo 'pójdziecie na Wielkanoc'. Istotnie niebawem zaczęto nas zwalniać. [...] Mnie zwolniono 15 kwietnia [1945 r.]. Obrośniętym z workiem wróciłem do domu)» ${ }^{93}$.

К собственным невзгодам, пережитым в связи с арестом и заточением, добавилась в жизни Нарембского тревога о судьбе дочери. Ее арестовали в начале 1945 года, три месяца она провела в той же тюрьме в Лукишках, где находился ее отец; в марте ее отправили в так называемый «фильтрационный лагерь» НКВД (№0321) в деревне Ельшанка под Саратовым, где ее продержали еще несколько месяцев, несмотря на отсутствие каких-либо обвинений (формально ее держали в тюрьме и лагере как «лицо, временно задержанное для проверки документов»), и освободили только в сентябре 1945 года ${ }^{94}$.

${ }^{93}$ Ibid, c. $38-40$.

94 Об этом подробнее в: Barbara Narębska-Dębska. 1920-2000. Grafika [Katalog], red. A. Rissmann, Toruń 2010, c. 14. 


\section{0. РЕПАТРИАЦИЯ (1945 ГОД)}

После освобождения Нарембский пытался вернуться к творческой работе в области архитектурно-художественного проектирования. В 1944-45 годах (до ареста и после выхода из тюрьмы) он работал главным инженером организации «Литстройпроект» (строительно-проектного бюро «Литовской ССР»), и кажется, делал все возможное, чтобы остаться в Вильнюсе, где его творческий опыт и труд мог быть востребован. Одним из последних в ряду бывших профессоров УСБ он понял абсолютную невозможность оставаться в «советском» Вильнюсе и необходимость репатриации. Сам художник писал об этом: «В тюрьме мне пришлось многое переоценить [...] Я отдал себе отчет в необратимости исторических процессов. Я понял, что там, где мы [поляки] оказались в меньшинстве, мы, конечно, еще можем сохранить свое положение (скорее, возможность сосуществования), свои права и в какой-то мере (в сильно уменьшенном объеме) все, чем мы владели, но для этого нужно или взаимное [с литовцами] желание, или применение силы для защиты наших прав. Эта альтернатива явно бессмысленна, ибо силы у нас нет, а если бы такая сила и была, я не хотел бы запятнать польское имя грубым насилием или обидой, нанесенной соседям. Таким образом, я покорился неизбежности и принял решение покинуть Вильнюс (W więzieniu wypadło wiele pojęć przewartościować [...] Zdałem sobie sprawę z nieodwracalności procesów historycznych. Zrozumiałem, że tam, gdzie jesteśmy w mniejszości, możemy uzyskać możność zachowania stanu uszczuplonego posiadania, raczej koegzystencji, ale do tego trzeba obopólnej chęci albo uzyskać supremację drogą siły. Ta alternatywa - jawnie nonsensowna, bo siły nie mamy, a gdybyśmy ją nawet mieli, nie chciałbym splugawić brutalną przemocą czy krzywdą imię polskie. W ten sposób pogodziłem się z wyjazdem z Wilna)» ${ }^{95}$.

Переезд семьи Нарембских в Польшу состоялся летом 1945 года.

${ }^{95}$ Archiwum UMK w Toruniu, K-9/360, Akta osobowe. Narębski Stefan, 19451962, Pamiętniki, c. 40. 
У нас нет точных данных о том, как сумел Стефан Нарембский решить вопрос с перевозом из Вильнюса в Польшу своего творческого архива. Несомненно, многое из тех художественных ценностей, какими он обладал в Вильнюсе, бесследно пропало. Из Мемориала, составленного 11 июля 1945 года Начальником Отдела культуры и печати при Управлении Главного Уполномоченного Правительства Польской Республики по делам эвакуации [поляков] из Литовской ССР по вопросу о «польских культурных ценностях, находящихся в личной собственности [подлежащих репатриации поляков]», - чрезвычайно интересного исторического документа, ставшего достоянием общественности лишь в конце XX века ${ }^{96}$, мы знаем, какие непреодолимые трудности встречали поляков, пытавшихся вывезти при репатриации собственные художественные коллекции, картины, предметы мебели, книги (свои библиотеки), инструменты художественного ремесла. Если для большинства польских репатриантов такого рода предметы были редким достоянием, то для художников невозможность вывоза их произведений и инструментов означала колоссальную утрату. Многое надо было начинать от нуля.

Дорога репатриации приводит Нарембского сначала в Лодзь, откуда он вскоре переезжает в Торунь. С переездом в Торунь в 1945 году Нарембский активно включается в организационную работу по созданию нового университета - имени Николая Коперника, который по замыслу его основателей должен был продолжить в послевоенной Польше традиции УСБ.

О преемственности традиций между УСБ и УНК свидетельствует уже сам факт создания в торуньском университете Отделения изобразительных искусств. Единственным польским университетом, который имел такое отделение, был УСБ в Вильнюсе, и именно такое отделение создается в молодом торуньском университете. Значительная часть профессорско-преподавательского состава этого Отделения формировалась из выпускников, а также бывших профессоров, доцентов и ассистентов УСБ, переехавших

${ }^{96}$ См.: Memoriat kierownika Referatu Kultury i Prasy w urzędzie Głównego Petnomocnika Rządu RP do spraw Ewakuacji z LSRR w sprawie polskich dóbr kultury na Litwie, stanowiacych wtasność prywatna [в книге:] Przesiedlenie ludności polskiej z Kresów Wschodnich do Polski 1944-1947, red. St. Ciesielski, Warszawa 1999, c. 234-240. 
из Вильнюса в Польшу на волне того великого «ухода» (exodus) польской интеллигенции из Литвы, который был обоснован правом на репатриацию в соответствии с соглашением, заключенным в Люблине 22 сентября 1944 года между правительством «Литовской ССР» и «Польским Комитетом Национального Освобождения» ${ }^{97}$, и продолжался с марта 1945 до октября 1946 года.

${ }^{97}$ Полный текст этого Соглашения опубликован историком Станиславом Чешельским в книге: Przesiedlenie ludności polskiej z Kresów Wschodnich do Polski 1944-1947, red. St. Ciesielski, Warszawa 1999, с. 55-62; там же приведены справки о численности отправленных в Польшу эшелонов («транспортов») с репатриантами. Из Справки, составленной Главным Уполномоченным Временного Правительства Польской Республики по делам «эвакуации поляков из Литовской ССР» 22 марта 1945 года, следует, что начавшаяся 28 декабря регистрация лиц, желающих выехать из Литвы в Польшу, практически закончилась 11 марта 1945 года; из 103.000 жителей Вильнюса польской национальности зарегистрировались как будущие репатрианты 102.348 человек, то есть 99\% всех вильнюсских поляков (Ibid, c. 111). Этот расчет касается только горожан - жителей Вильнюса: среди жителей сельских местностей и маленьких городков Вильнюсского края процент людей, готовых оставить свои дома и хозяйства и переехать в Польшу, был гораздо ниже, что и привело к формированию довольно многочисленного (около 300.000 человек) польского меньшинства, почти абсолютно лишенного своей столичной интеллигенции, в Литовской ССР. Всего, как следует из секретного сообщения Наркома внутренних дел СССР С.Н. Круглова на имя Председателя Совнаркома В.М. Молотова (от 26 февраля 1946 года) «в Литовской ССР зарегистрировано 367.861 человек, выразивших желание выехать в Польшу, выехало 34.584 семей; подало заявлений о переселении в Литву [из Польши] 56 человек, эвакуировано 14 человек (Ibid, c. 416); формально объявленная как «встречная», или «взаимная» (поляки «добровольно» переселяются из Литвы в Польшу, литовцы - из Польши в Литву), на самом деле совершалась не на «равных» началах: из Советского Союза шел массовый исход поляков, из Польши в СССР никто переезжать не хотел. 


\section{1. ПОСЛЕВОЕННЫЕ ГОДЫ В ТОРУНИ. УНИВЕРСИТЕТ НИКОЛАЯ КОПЕРНИКА}

Университет Николая Коперника в Торуни, возглавленный ректором Людвиком Колянковским (Ludwik Kolankowski, 1882-1956), бывшим в 1919 году одним из основателей, а затем профессором УСБ в Вильнюсе, начал свою деятельность в послевоенной Польше в 1945 году. На должность профессора УМК приказом ректора Л. Колянковского Нарембский был зачислен 8 октября 1945 года.

В 1946-1948, 1951-1952 и 1960-1962 годах Нарембский был деканом Отделения Изобразительных искусств УМК ${ }^{98}$, и все обязанности, связанные с руководством учебным процессом, с подбором и расстановкой кадров педагогов, с формированием и реорганизацией мастерских и кафедр, с участием в общей научной и общественной жизни университета в это непростое и нелегкое для всей польской интеллигенции время, он сочетал с собственной преподавательской работой, оставаясь в течении семнадцати лет, в 19451962 годах руководителем кафедры проектирования интерьеров.

Программа этой кафедры, разработанная Нарембским, предусматривала «решение художественных проблем [пластической выразительности интерьера] путем создания проектов двухмерных и трехмерных композиций (на плоскости и в пространстве) от самых элементарных.. до наиболее сложных и связанных с определенной функцией (.rozwiązanie problemów plastycznych poprzez projektowanie kompozycji w płaszczyźnie i przestrzeni od najbardziej podstawowych... do coraz bardziej skomplikowanych i powiązanych $\mathrm{z}$ określoną

${ }^{98}$ Надо отметить, что в 1946 году он был выбран на должность декана и стал, таким образом, вторым после Ямонтта и последним в истории УНК «избранным» деканом Отделения Изобразительных Искусств. Уже в конце 1948 года, как отмечает профессор Юзеф Флик, «над Отделением изобразительных искусств стали сгущаться темные тучи [...] эта угроза исходила сверху, от варшавской власти, стремившейся к централизации управления и к ограничению демократических начал в соответствии с общими партийными установками политиков, которых начали раздражать прежние университетские привилегии, особенно обучение художников, ориентированное на современное искусство Европы и мира» (J. Flik, Sukcesy i porażki Wydziału Sztuk Pięknych (Próba syntezy) [в книге:] 60-lecie Uniwersytetu Mikołaja Kopernika w Toruniu, red. Cz. Łapicz,W. Wróblewski, Toruń 2006, с. 95-105; здесь с. 96). 
funkcją)"99. Проводились занятия по перспективе и другим дисциплинам, необходимым для развития архитектурного мышления. Большое внимание в процессе обучения уделялось мастерству обработки различных материалов. Как важнейший элемент художественного оформления интерьера рассматривалась мебель, и проектирование мебели было одним из приоритетных направлений в работе кафедры. Часть занятий проходила в столярной мастерской. Кафедра имела многопрофильный характер. С одной стороны, она давала практические навыки, готовила мастеров архитектурного дизайна, чей труд был востребован для решения задач комплексного оформления (создания обстановки, мебели, декорации) разнообразных общественных интерьеров в новых постройках и при перестройке (приспособлении к новым функциям) старых зданий, при этом в обязательную программу обучения входило изучение памятников (zabytkoznawstwo), научных основ консервации и реставрации художественных ценностей. С другой стороны, перед воспитанниками кафедры раскрывались широкие возможности творческих экспериментов в различных направлениях новейшего искусства (от близкого, «западного» влияния Польша даже в суровую пору второй половины 1940-х и первой половины 1950-х годов $^{100}$ не была изолирована, а со временем все более свободно и последовательно приобщалась к открытиям абстракционизма, опарт, «кинетического» искусства, «новой вещественности» и других направлений). Воспитанные в духе понимания эстетической самоценности пластической формы, молодые художники могли дать волю своей фантазии в комбинации таких форм на плоскости и в пространстве, в поисках оптических и колористических эффектов. Определенная логика была в том, что впоследствии, уже после

${ }^{99}$ Цитировано по источнику: R. Depta, Wydziat Sztuk Pięknych Uniwersytetu Mikotaja Kopernika w Toruniu, Katedra Projektowania wnętrz - Zakład Ksztatcenia Form Plastycznych [в книге:] Kształcenie artystyczne w Wilnie i jego tradycje / Vilniaus Meno mokykla ir jos tradicijos, red. katalogu J. Malinowski, M. Woźniak, R. Janoniene, Toruńn 1996, c. 207.

${ }_{100}$ Культурная политика ПНР этих лет, включавшая и «борьбу с формализмом», и «борьбу с космополитизмом», и насаждение метода «социалистического реализма», распространялась на всю страну, включая, разумеется, и Торунь, но авторитет «ветеранов вильнюсской школы» всегда составлял довольно мощную, противодействующую этой политике силу (см. об этом: J. Bogucki, Działalność Tymona Niesiołowskiego na tle życia artystycznego Torunia w latach 1945-1960, „Bydgoski Rocznik Muzealny” 1969 , nr 1, c. 108-131). 
смерти Нарембского, кафедра проектирования интерьеров была преобразована в Отдел формирования пластических форм (Zakład Kształtowania Form Plastycznych). Разрабатывая программу кафедры, Нарембский выступал как теоретик новаторского направления художественной педагогики.

Нарембский выступает также как один из первых в польском искусствознании историков системы художественного образования пишет исторический очерк Отделение изобразительных искусств Университета Николая Коперника для юбилейного издания к 10-летию этого университета ${ }^{101}$. Следующее десятилетие в истории этого Отделения получает освещение в его одноименной статье, включенной в издание Университет Николая Коперника 1956-1965 $5^{102}$.

Так же, как в довоенный период, много сил отдает Нарембский исследовательской работе в области истории искусства: публикует статьи Ренессансная часовня во Влочлавке и ее связи с часовней Фирлейев в Бейсиах (Kaplica renesansowa we Włocławku i jej związki z kaplica firlejowska w Bejscach) (1961) и Людвик Бухард - учитель Ноаковского (Ludwik Bouchard nauczyciel Noakowskiego) (1965); до самых последних дней своей жизни работает над исследованием истории европейского мебельного дела (этот труд был издан уже после его смерти в 1966 году, и как замечает Ежи Фрыч, «навсегда вписал имя профессора Нарембского в историю польского искусствознания, исследующего художественное ремесло» ${ }^{103}$.

В 1953 году Центральная Квалификационная Комиссия (польский аналог советской ВАК - Высшей Аттестационной Комиссии) присваивает ему ученую степень доктора наук в области изобразительного искусства.

Параллельно с педагогической и научно-исследовательской деятельностью Нарембский ведет творческую работу как архитектор и реставратор; занимает должность сначала заместителя главного консерватора памятников архитектуры Куявско-Поморского воеводства (в 1947-1949 годах), а затем главного воеводского консерватора (в 1949-1950 годах), руководит архитектурным отделением

${ }^{101}$ S. Narębski, Wydziat Sztuk Pięknych UMK [в книге:] Uniwersytet Mikołaja Kopernika. 1945-1955, red. R. Galon, Warszawa 1957.

${ }_{102}$ S. Narębski, Wydziat Sztuk Pięknych UMK [в книге:] Uniwersytet Mikołaja Kopernika. 1956-1965, red. R. Galon, Toruń 1965.

103 J. Frycz, Stefan Narębski (1892-1966), architekt, profesor UMK [в книге:] Toruńscy twórcy nauki i kultury (1945-1958), red. Marian Biskup, Andrzej Giziński, Warszawa - Poznań - Toruń 1989, с. 235-240; здесь с. 238. 
в Мастерской Консервации Памятников (Pracownia Konserwacji Zabytków) (1951-1954), является членом Комиссии по вопросам культуры при Президиуме Воеводского Совета в Быдгощи, Совета по охране памятников в Торуни и Ольштине.

Одной из первых его работ послевоенного периода является Павильон Дирекции Государственных Лесов на Выставке промышленности, ремесла и торговли, организованной в Быдгощи в 1946 году. При его проектировании Нарембский вновь (как в довоенный период при сооружении костелов) обращается к традициям деревянной народной архитектуры и создает сооружение, напоминающее деревенский костел под высокой двускатной крышей с примыкающей к нему башней, подобной звоннице.

Совершенно иначе, в духе строгого функционализма возводит Нарембский здание физико-химического факультета Университета Николая Коперника (Collegium Physicum) в Торуни. В данном случае он руководствуется тем проектом торуньского архитектора Збигнева Валя (Zbigniew Wahl), который еще до войны был взят за основу сооружения здания Апелляционного суда (строительство не успели довести до конца до 1939 года, а после войны этот объект был передан Университету Николая Коперника). Здание отличается строгими очертаниями, четким рисунком главного фасада с длинными рядами прямоугольных окон, отсутствием каких-либо декоративных излишеств и производит величественное и торжественное впечатление.

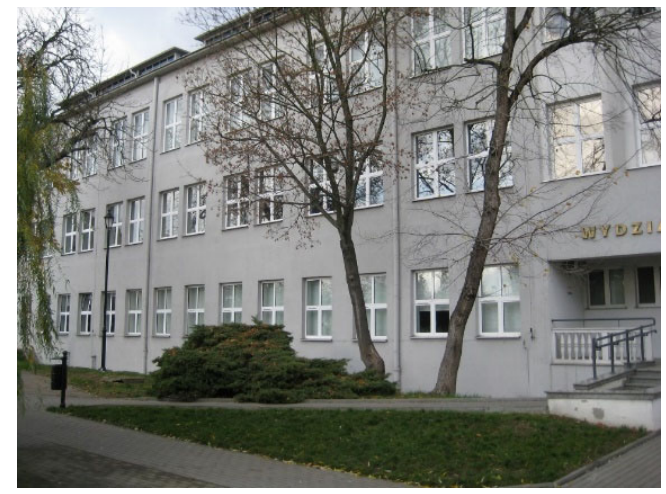

Илл. 12. Збигнев Валь (до 1939), Стефан Нарембский (после 1945), Collegium Physicum (ныне здание факультета математики и информатики Университета Николая Коперника) в Торуни. Современное состояние 
По проектам Нарембского были осуществлены работы по реставрации женского бенедиктинского монастыря в Грудзьондзе (Grudziądz), ратуши в старом городе (помещений, преобразованных в Окружной музей, включая залы, предназначенные для экспозиции, для заседаний и конференций, лестничные площадки и пролеты, стильную мебель в интерьерах $)^{104}$, корчмы «Pod Modrym Fartuchem (Под синим фартуком)» и других объектов в Торуни.

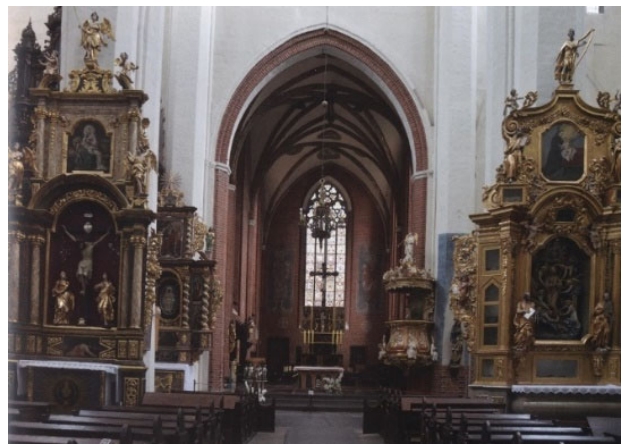

Илл. 13. Стефан Нарембский, Пресвитерий кафедрального собора Св. Яна в Торуни, реконструкция 1949

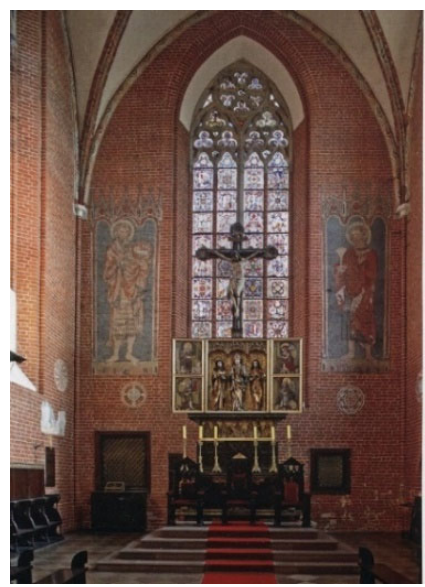

Илл. 14. Стефан Нарембский, Интерьер кафедрального собора Св. Яна в Торуни, алтарь, реконструкция 1949

104 Подробный анализ проведенной Нарембским реконструкции торуньской ратуши содержится в статье: J. Frycz, Muzeum w ratuszu toruńskim, „Pomorze” 1964, nr 20. 
Червонная С. М.

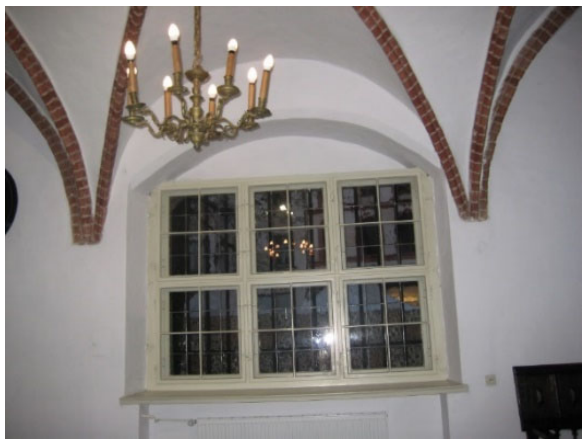

Илл. 15. Стефан Нарембский, Интерьер Городской Ратуши в Торуни, реконструкция 1960-1964

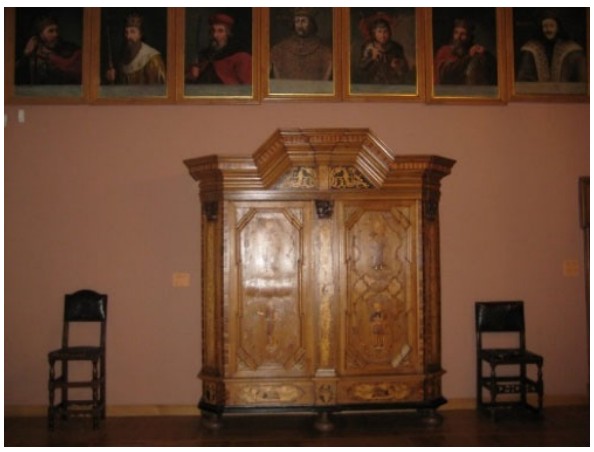

Илл. 16. Стефан Нарембский, Мебель для интерьера городской ратуши в Торуни, реконструкция 1960-1964

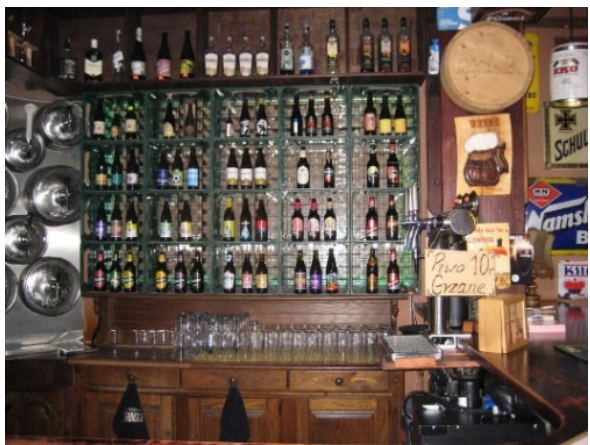

Илл. 17. Стефан Наремюский, Интерьер корчмы «Под синим фартуком» в Торуни, после 1946 
Он создал также проект памятника воинам Советской Армии (точное название - «монумент благодарности Советской Армии») для города Быдгощ. Этот проект был отмечен премией по итогам конкурса 1949 года ${ }^{105}$. В 1961 году он создает проект памятника для селения Пловцы (Płowce) Куявско-Поморского воеводства в память о победе, одержанной здесь в 1331 году польским войском под предводительством короля Владислава I Лакетки (Władysław I Łakietka) в битве с крестоносцами.

Заслуги Нарембского получили высокую оценку в послевоенной Польше. Он был награжден офицерским крестом и Орденом Возрождения Польши (Krzyżem Oficerskim i Kawalerskim Orderu Odrodzenia Polski), Золотым крестом за заслуги перед Отечеством (Złotym Krzyżem Zasługi) и другими наградами.

Своего рода продолжением «дома Нарембского» в Торуни в 1960-70-х годах, был дом, или как его часто называли «салон» Козловских - маленькая квартирка дочери Нарембского Барбары и ее второго мужа - художника, скульптора, архитектора, мастера проектирования интерьеров Юзефа Козловского ${ }^{106}$. Как вспоминает об этом «салоне» часто бывавший там профессор права Станислав Салмонович, был он притягательным центром для интеллигенции, находившейся в оппозиции к коммунистическому режиму; здесь царил культ памяти маршала Пилсудского, была собрана целая коллекция его портретов и предметов, напоминающих о его роли в воз-

${ }^{105}$ Archiwum UMK, K 9 / 360, Stefan Narębski, Akta Osobowe.

106 Józef Kozłowski, родился в 1905 году, происходил из среды польской шляхты, проживавшей на «Восточных Кресах» (землях нынешней Украины), учился в Киевской гимназии (1917-1920), в годы гражданской войны, как доброволец, участвовал в походе польской армии - наступлении на Киев; после 1918 года принял польское гражданство, окончил Школу изобразительных искусств в Познани (1929), затем работал в Варшаве, с 1947 года был доцентом УНК (Archiwum UMK w Toruniu, K 19/89, Józef Kozłowski, Akta Osobowe). Как пишет Юзеф Флик, «... Професcop Юзеф Козловский, великолепный акварелист и проектировщик, поклонник Юзефа Пилсудского, о котором с восторгом рассказывал коллегам и студентам [...] после Нарембского возглавил кафедру проектирования интерьеров» (J. Flik, Sukcesy i porażki Wydziału Sztuk Pięknych (Próba syntezy) [в книге:] 60-lecie Uniwersytetu Mikołaja Kopernika w Toruniu, red. Cz. Łapicz, W. Wróblewski, Torun 2006, с. 95-105, здесь s. 99). 
рождении польского государства; обязательным моральным императивом для всех, посещавших этот салон, была полная свобода высказываний по политическим вопросам ${ }^{107}$.

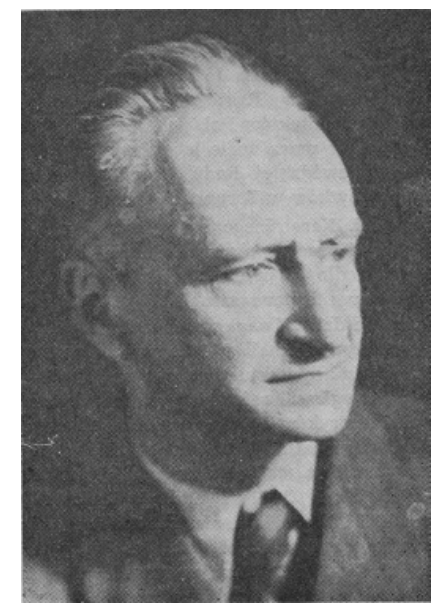

\section{Илл.18. Стефан Нарембский а Торуни, фотография около 1960 г. в Торуни}

Умер Стефан Нарембский 16 ноября 1966 года в Варшаве ${ }^{108}$, похоронен в Торуни на кладбище Св. Юзефа. Надгробный памятник над его могилой сооружен по проекту его зятя Юзефа Козловского. Он же после смерти Нарембского становится руководителем кафедры проектирования интерьеров, продолжая в 1960-70-х годах дело своего бывшего руководителя и духовного наставника.

107 Cм.: St. Salmonowicz, Wspomnienia o profesorach $i$ o „, salonach” toruńskich lat sześćdziesiatych i siedemdziesiatych [w:] 60-lecie Uniwersytetu Mikołaja Kopernika w Toruniu, red. Cz. Lapicz, W. Wróblewski, Toruń 2006, с. 223-232, здесь с. 228-229.

${ }^{108}$ Некролог о его смерти от имени Ректора и Сената Университета Николая Коперника извещал «о тяжелой утрате выдающегося польского художниуа, ученого и педагога / o bolesnej stracie wybitnego polskiego artysty, naukowca i pedagoga» (Archiwum UMK, K-9/360. Akta Osobowe. Stefan Narębski). 


\section{ЗАКЛЮЧЕНИЕ}

Подводя итог всему, что мы знаем о творчестве Стефана Нарембского, мы можем сказать, что, несмотря на несомненное признание, каким он пользовался у своих современников и учеников, все же его творческий вклад в искусство и архитектуру Польши, в систему художественного образования, в развитие художественной педагогики еще не в полной мере оценен общественностью и художественной критикой, а в публикациях, освещающих его творчество и жизненный путь, встречаются неточности, ошибки и остаются многие «белые пятна», заполнить которые (и то далеко не все) можно лишь с помощью архивных материалов, в том числе впервые публикуемых в настоящей статье. Личность Нарембского представляет собой тот редкий для культуры XX века тип многогранного, почти универсального художника и педагога, чье творческое наследие не укладывается в прокрустово ложе какого-либо одного вида искусства, а тем более одного жанра или художественного направления ${ }^{109}$.

На стыке различных направлений, прежде всего модернистских и «традиционалистских» течений, сотрясавших (и в то же время посвоему обогащавших) культуру Восточной Европы XX века, он умел найти не только «золотую середину», но и весьма эффективные (хотя открыто не декларированные) средства противостояния тому тотальному наступлению на искусство идеологической пропаганды, в частности, императивов «социалистического реализма» 1940-50-х годов, от которого совершенно свободна была созданная и руководимая Нарембским кафедра «проектирования интерьеров», или «формирования пластических форм» Университета Николая Коперника, где учащиеся ценили эстетическую самоценность этих «пластических форм» и имели возможность их фантастических комбинаций «на плоскости и в пространстве».

109 «Он был не только художник, - писал о Нарембском его современник, известный польский историк искусства Богуслав Мансфельд. - Его натура ренессансного типа соединяла талант архитектора с мастерством реставратора, вкус художника со знаниями историка искусства, увлеченность педагога с ангажированностью общественного деятеля» (B. Mansfeld, Żegnajac Stefana Narębskiego, „Pomorze” 1966, nr 24, c. 14). 
Биография Нарембского чрезвычайно интересна как нить, связующая разные исторические этапы и политические режимы, разные географические ареалы и центры польской культуры (Варшава, Влоцлавек, Вильнюс, Торунь), разные сферы творческой деятельности, включая архитектурное проектирование и строительство, декоративное искусство, дизайн, реставрацию и приспособление к новому функциональному назначению памятников старины, науку изучения этих памятников в широком контексте истории национального и мирового искусства, художественную критику, теорию и практику художественной педагогики, станковую графику (рисунок, карикатуру). Если можно так сказать, «чисто польский» художник (по происхождению, самосознанию, воспитанию, языку, культуре, месту постоянного проживания: за свою жизнь он даже «за границей» бывал редко, если не считать «заграницей» Литву, Белоруссию, Украину или Россию, чьи земли в то время, когда он там жил, формально еще не находились «за границами» польского государства), он работал не только для своей страны. В то же время он постоянно находился в тени тех угроз, которые нависали над Польшей и с Запада, и с Востока. Интереснейшие - и мало известные - страницы его биографии (участие в молодежном движении, поднявшемся на окраинах Российской империи на волне революции 1905 года; увлечение фантомами социал-демократии; тяжелейшие моменты, пережитые в годы нацистской и советской оккупации, когда короткая дорога из гестаповской тюрьмы в Лукишках 1943 года вела его в казематы НКВД, разместившиеся в тех же Лукишках, в 1944 году, а участие в подпольном антифашистском движении сопротивления и пребывание в немецком концлагере / «трудовом лагере» в Парвенишках не только не служили «охранной грамотой» и поводом для признания его заслуг, но вызывали усиленное подозрение советской власти и приводили к новым репрессиям с ее стороны) становятся наглядным воплощением драматических коллизий той эпохи, к которой принадлежат его жизнь и творчество. 


\section{БИБЛИОГРАФИЯ}

1. Andriulytė Algè, Ferdynandas Ruszczycas, Civis Vilnensis sum, Vilniaus Dailès Akademijos Leidykla, Vilnius 2018.

2. Barbara Narębska-Dębska. 1920-2000. Grafika, Agata Rissmann (автор составитель), [katalog wystawy / каталог выставки]. Muzeum Okręgowy w Toruniu, Torun 2010.

3. Bogucki, Janusz, Działalność Tymona Niesiołowskiego na tle życia artystycznego Torunia $w$ latach 1945-1960, „Bydgoski Rocznik Muzealny" 1969, nr 1, c. 108-131.

4. „Budowa gmachu Muzeum Ziemi Kujawskiej”, Życie Włocławka i Okolicy, 11-12 (1928), c. 15-18.

5. Budreika, Eduardas, „Gedimino kalno Pilies Vilniuje Vakarinio bokšo rekonstrukcijos“, Metraštis 1958, s. 6.

6. Butvilaitè, Rasa: „Public buildings in the Interwar Vilnius” [B книге:] Międzynarodowa konferencja naukowa "Międzywojenne Wilno: kształty sztuki $i$ architektury $w$ latach 1919-1939" / International Conference "Interrwar Vilnius: Shapes of Art and Architecture in 19191939”, Wytauto Kasiulio Muziejus, Vilnius 2019, c. 30.

7. Butvilaitė, Rasa; Povilaitytė-Leliugienè, Edita; Vilniaus rotušes pertvarkymas bei prytaikymas Vilniaus miesto muziejui [в книге:] (Ne)matomas Vilnius: tarpukario dailès ir architektūros pavidalai. Parodos katalogas. Vytauto Kašiulio dailès muziejus, 2018 m. liepos 12 d. - rugsejjo 16 d. / (In)visible Vilnius: Shapes of interwar Art and Architecture. Exhibition catalogue. Vytautas Kasiulis Art Museum 12 Juky - 13 September 2018,, red. Algè Andriulytė, Rasa Burvilaitè, Ilona Mažeikienė, Vilnius 2018, c. 16.

8. Churski, Andrzej, „Narębski Point”, Nowości, 113 (1998), c. 9.

9. Ciesielski, Stanisław (автор-составитель), Przesiedlenie ludności polskiej z Kresów Wschodnich do Polski 1944-1947, Wydawnictwo NERITON, Instytut Historii PAN, Warszawa 1999.

10. Čaplinskas, Antanas Rimvydas, „Narembskis Stefanas architektas, profesorius“ [в книге:] Čaplinskas, Antanas Rimvydas, Vilniaus atminimo knyga, Vilnius 2011.

11. „Dailés mokyklų statymas”, Vyriausybès Žinios, 706 (1940), eil. [ordinal number] 5439.

12. Dawidowicz, Aleksander, „Profesor Stefan Narębski projektant, i odnowiciel zabytków Wilna”, Nasza Gazeta, 43 (1996), c. $7-8$. 
13. Depta, Ryszard, „Wydział Sztuk Pięknych Uniwersytetu Stefana Batorego w Toruniu, Katedra Projektowania wnętrz - Zakład Kształcenia Form Plastycznych" [в книге:] Ksztatcenie artystyczne w Wilnie i jego tradycje - Vilniaus meno mokykla ir jos tradicijos - Fine art education in Vilnius and its tradition, Jerzy Malinowski, Michał Woźniak, Rūta Janoniené (авторы-составители), katalog wystawy [каталог выставки], Muzeum Okręgowy w Toruniu, Uniwersytet Mikołaja Kopernika, Vilniaus dalès akademija, Toruń 1996, c. 206-208, 441-444.

14. Drèma, Vladas, Łotentz, Stanisław; Laiškai / Listy, Vilniaus Dailès Akademijos Leidykla, Vilnius 1998.

15. Dubowik, Henryk; Malinowski, Leszek (отв. редакторы, авторы-составители): Encyklopedia Ziemi Wileńskiej, t. I, Wileński słownik biograficzny, Wydawnictwo: Towarzystwo Miłośników Wilna i Ziemi Wileńskiej, Bydgoszcz 2002.

16. Ferdynand Ruszczyc: Życie i dzieło, Grafika, Wilno 1939.

17. Flik, Józef, „Sukcesy i porażki Wydziału Sztuk Pięknych (Próba syntezy)" [в книге:] 60-lecie Uniwersytetu Mikotaja Kopernika w Toruniu, Łapicz, Czesław; Wróblewski, Witold (редакторысоставители), Wydawnictwo naukowe UMK, Toruń 2006, с. 95-105.

18. Frycz, Jerzy, „Muzeum w ratuszu toruńskim”, Pomorze, 20 (1964), c. 1-2.

19. Frycz, Jerzy, „Prof. Stefan Narębski (1892-1966)”, Architektura 8 (1967), c. 336.

20. Frycz, Jerzy, „Stefan Narębski (1892-1966), architekt, profesor UMK" [в книге:] Biskup, Marian; Giziński, Andrzej (составители), Toruńscy twórcy nauki i kultury (1945-1958), Państwowe Wydawnictwo Naukowe, Warszawa - Poznań - Toruń 1989, c. 235-240.

21. [Frycz, Jerzy], Narębski Stefan [в книге:] Polski Słownik Biograficzny, t. 22, Wrocław 1977, c. 540-542.

22. Galon, Raimund (редактор), Uniwersytet Mikołaja Kopernika. 1945-1955, Warszawa 1957.

23. Galon, Raimund (редактор), Uniwersytet Mikołaja Kopernika. 1956-1965, Toruń 1965.

24. Górski, Karol, „Stefan Narębski - architekt, humanista”, Pomorze, 23 (1968), c. 68.

25. Grzeluk, Izydor, „Stefana Narębskiego 'Uwagi o meblarstwie wileńskim' ", Kwartalnik Historii Kultury Materialnej, 4 (1996), c. 415-429. 26. Hankowska, Romualda, „Stefan Narębski (1892-1966), artysta 
malarz, profesor UMK" [в книге:] Zastużeni dla Włocławka, Wojciechowski, Mieczysław (редактор-составитель), Włocławskie Towarzystwo Naukowe, Włocławek 1991, c. 147-148.

27. Hołyński, Józef, „Słowiańskie mniejszości narodowe w Polsce”, Życie Włocławka i Okolicy, 2 (1926), c. 9-11.

28. Horoszkieczówna, Walentyna, „Promienisty. Prof. Ludwik Janowski”, Alma Mater Vilnensis , 1 (1922), c. 42.

29. Jankevičiūtè, Giedrè, Bažnytinè dailè nacių okupoutoje Lietuvoje, Vilnius 2011, c. 193-232

30. Jankevičiūtè, Giedrè, Lentvario baničia ir jos dekoras 19051943, Vilnius 2012.

31. Kłos, Juliusz, Wilno, Przewodnik krajoznawczy, wyd. I, Wydawnictwo Oddziału Wileńskiego Polskiego Towarzystwa Krajoznawczego, Wilno 1923.

32. Ksztatcenie artystyczne $w$ Wilnie i jego tradycje - Vilniaus meno mokykla ir jos tradicijos - Fine art education in Vilnius and its tradition, Jerzy Malinowski, Michał Woźniak, Rūta Janonienè (авторысоставители), katalog wystawy [каталог выставки], Muzeum Okręgowy w Toruniu, Uniwersytet Mikołaja Kopernika, Vilniaus dalès akademija, Toruń 1996.

33. Likwidacja Uniwersytetu Stefana Batorego przez władze litewskie w grudniz 1939 roku, Piotr Łossowski (составитель и автор вступительной статьи), Wydawnictwo INTERLIBRO, Warszawa 1991.

34. Lorentz, Stanisław, Album wileńskie, Państwowy Instytut Wydawniczy, Warszawa 1980.

35. Lorentz, Stanisław, Konserwacja wnętrza kościoła Ostrobramskiego w Wilnie, „Ochrona Zabytków”, cz. I, c. 212-216.

36. Maksymiuk, Małgorzata, Kościót pod wezwaniem Zwiastowania Najświętszej Marii Panny w Lanwarowie pod Wilnem, Poznań 2000.

37. Malinowski, Kazimierz, „Stefan Narębski 5 II 1892 - 15 XI 1966", Zeszyty Naukowe UMK. Zabytkoznawstwo i Konserwatorstwo 1966 (4), c. 3-4.

38. Małachowicz, Edmund, „Architektura dwudziestolecia międzywojennego w Wilnie" [в книге:] Architektura i urbanistyka w Polsce w latach 1918-1987, Wanda Puget (red.), Warszawa 1989, c. 121-141.

39. Mansfeld, Bogusław, „Stefan Narębski 1892-1966”, Rocznik Kulturalny Kujaw i Pomorza 1977-1978, c. 153-160. 
40. Mansfeld, Bogusław, „Żegnając Stefana Narębskiego”, Pomorze, 24 (1966), c. 13-14.

41. Meysztowicz, Walerian, Gawędy o czasach $i$ ludziach, Wydawnictwo: Polska Fundacja Kulturalna, Londyn 1983.

42. Miłosz, Czesław, Zaczynajac od moich ulic, Instytut Literacki, Paryż 1985.

43. Narębska-Dębska, Barbara, Bibliografia prac prof. Stefana Narębskiego, „Biuletyn Historii Sztuki” 1967, nr 2, c. 225-226.

44. Narębska, Barbara, „Wilno” [в книге:] Wileńskie środowisko artystyczne 1919-1945, malarstwo, grafika, rzeźba, rysunek, fotografia, Kazimierz Brakoniecki (автор выставки, составитель каталога), katalog wystawy [каталог выставки], Galeria Sztuki Współczesnej w Olsztynie, [Olsztyn 1989], c. 7.

45. Narębski, Stefan, „Możliwości architektoniczne Wilna”, Środy Literackie, 3 (1936), c. 1-6.

46. Narębski, Stefan, „O racjonalne zabudowanie przedmieść Włocławka”, Życie Włocławka i Okolicy, 1 (1926), c. 7-9.

47. Narębski, Stefan, „Uwagi nad rozwojem planu i nad regulacją Włocławka”, Życie Włocławka i Okolicy, 2 (1927), c. 6-9.

48. Narębski, Stefan, „Zagadnienia architektury nowoczesnej”, Życie Włocławka i Okolicy, 3 (1927), c. 12.

49. Narębski, Stefan, „Zarys rozwoju urbanistycznego Wilna i plan zabudowania z roku 1817", Prace i materiaty Sekcji Historii Sztuki Wileńskiego Towarzystwa Przyjaciót Nauk, 2 (1935), c. 339-345.

50. (Ne)matomas Vilnius: tarpukario dailess ir architektūros pavidalai. Parodos katalogas - (In)visible Vilnius: Shapes of interwar Art and Architecture. Exhibition catalogue. Algè Andriulytè, Rasa Butvilaitè, Ilona Mažeikienė (авторы-составители), [каталог выставки], Vytauto Kasiulio dailès muziejus, Vilnius 2018.

51. Od redakcji [Narębski, Stefan, „Od redakcji”], Życie Włoctawka i Okolicy", 2 (1926), c. 2.

52. Ostatni dni Uniwersytetu Stefana Batorego. Świadectwo dokumentalne, Łossowski Piotr (сосставитель и автор комментариев). Uniwersytet Warszawski, Wydział Dziennikarsywa i Nauk Politycznych, 2012.

53. Piwocki, Ksawery, „Stefan Narębski”, Biuletyn Historii Sztuki, 3 (1967), c. 224-226.

54. Po raudonaja žvaigžde. Lietuvos daile 1940-1941 m., Parodos knyga, [книга-путеводитель по выставке], Jankevičiūtè, Giedré 
(автор-составитель) Lietuvos kultūros tyrimų institutas, Vilnius 2011.

55. Poklewski, Józef, Polskie życie artystyczne $w$ międzywojennym Wilnie, Uniwersytet Mikołaja Kopernika, Toruń 1994.

56. Poklewski, Józef, „Wileńsko-nowogródzki okręg konserwatorski w okresie międzywojennym", Acta Universitatis Nicolai Copernici. Zabytkoznawstwo i konserwatorstwo, 1991, c. 215-230.

57. Poklewski, Józef, „Wydział Sztuk Pięknych Uniwersytetu Stefana Batorego 1919-1939" [в книге:] Ksztatcenie artystyczne w Wilnie i jego tradycje - Vilniaus meno mokykla ir jos tradicijos - Fine art education in Vilnius and its tradition, Jerzy Malinowski, Michał Woźniak, Rūta Janoniené (авторы-составители), katalog wystawy [каталог выставки], Muzeum Okręgowy w Toruniu, Uniwersytet Mikołaja Kopernika, Vilniaus dalès akademija, Toruń 1996, c. 97-149, 329-390.

58. Pszczółkowski, Michał, Architektura Uniwersytetu Mikołaja Kopernika, Wydawnictwo naukowe UMK, Torun 2009.

59. Pszczółkowski, Michał, Kresy nowoczesne. Architektura na ziemiach wschodnich II Rzeczypospolitej 1921 - 1939, Łódź 2016.

60. Przybyszewski, Kazimierz, „Z Włocławka do Torunia - przez Wilno, W stulecie urodzin prof. dr. S. Narębskiego", Nowości, 29 (1992), c. 4.

61. Rissmann, Agata, Twórczość Barbary Narębskiej-Dębskiej (1921-2000). Urodzona dla architektury wilnianka z Kujaw [в книге:] Barbara Narębska-Dębska. 1920-2000. Grafika, Agata Rissmann (автор составитель), [katalog wystawy / каталог выставки]. Muzeum Okręgowy w Toruniu, Toruń 2010, c. 5-9.

62. Ruszczyc, Ferdynand, Dziennik, t. 2., W Wilnie 1919-1939, Ruszczyc, Edward (red.), AOW Secesja, Warszawa 1996.

63. Rymaszewski, Bohdan, „Stefan Narębski (1892-1966). Wspomnienia pośmiertne o profesorze Stefanie Narębskim", Ochrona Zabytków 2 (1967): c. 57-58.

64. Salmonowicz, Stanisław, „Wspomnienia o profesorach i o „salonach” toruńskich lat sześćdziesiątych i siedemdziesiątych” [в книге:] Łapicz, Czesław; Wróblewski, Witold (редакторысоставители), 60-lecie Uniwersytetu Mikołaja Kopernika w Toruniu, Wydawnictwo naukowe UMK, Toruń 2006, c. 223-232.

65. Starzyński, Ludomir: „Kapitał i praca”, Życie Włocławka $i$ Okolicy”, 2 (1926), c. 11-12.

66. Stefan Narębski, Jerzy Frycz (автор-составитель), katalog 
wystawy [каталог выставки], Stowarzyszenie Historyków Sztuki, Oddział w Toruniu, Toruń 1967.

67. Stefan Narębski. 1892-1966. Architekt, konserwator, profesor, Michał Pszczółkowski (автор-составитель), katalog wystawy [каталог выставки], Muzeum Okręgowy w Toruniu, Toruń 2017.

68. 60-lecie Uniwersytetu Mikołaja Kopernika w Toruniu, Łapicz, Czesław; Wróblewski, Witold (редакторы-составители), Wydawnictwo naukowe UMK, Toruń 2006.

69. Supruniuk, Anna; Supruniuk, Mirosław Adam, Alma Mater Vilnensis 1919-1939. 100-lecie Uniwersytetu Stefana Batorego w Wilnie 1919-2019, Wydawnictwo naukowe UMK, Toruń 2019.

70. Toruńscy twórcy nauki i kultury (1945-1958), Biskup, Marian; Giziński, Andrzej (составители), Państwowe Wydawnictwo Naukowe, Warszawa - Poznań - Toruń 1989.

71. Vasiliūnienè, Dalia, Senu tapyba Perlojos bažničioje, „Menotyra“" (3), 2004, c. 36.

72. Wileńskie środowisko artystyczne 1919-1945, malarstwo, grafika, rzeźba, rysunek, fotografia, Kazimierz Brakoniecki (автор выставки, составитель каталога), katalog wystawy [каталог выставки], Galeria Sztuki Współczesnej w Olsztynie, [Olsztyn 1989].

73. Wilkus, Kazimierz, „Odkrycie grobów królewskich w katedrze wileńskiej" [в книге:] Wilno - Wileńszczyzna jako krajobraz $i$ środowisko wielu kultur, Towarzystwo Literackie im. Adama Mickiewicza, Białystok 1992, c. 105-114.

74. Zastużeni dla Włocławka, Wojciechowski, Mieczysław (редактор-составитель), Włocławskie Towarzystwo Naukowe, Włocławek 1991.

75. Zgorzelski, Czesław: „Alma Mater Vilnensis”, Ethos, 1 (1988), c. $72-88$.

76. Znajdziłowska, Barbara, ,'Ten dom budowat mój ojciec...",, Kurier Wileński 160 (1997), c. 1-2. 


\section{СПИСОК ИЛЛЮСТРАЦИЙ}

1. Диплом Варшавского Политехнического Института (выдан в 1923 г.) о присуждении Стефану Нарембскому звания дипломированного архитектора. Оригинал находится в: Archiwum UMK w Toruniu, K-9/360, Akta osobowe. Narębski Stefan, 1945-1962.

2. Стефан Нарембский, Проект деревенского костела, 1927. Эских находится в Музее архитектуры во Вроцлаве.

3. Стефан Наребский, Проект городского Музея (Музея Земли Куявской) для Влоцлавка, 1926. эскиз находится в Музее архитектуры во Вроцлавле.

4. Стефан Нарембский, Музей Земли Куявской во Влоцлавке, 1926-1930.

5. Здание бывшего Отделения изобразительных искусств Университета Стефана Батория на улице Св. Анны в Вильнюса (ныне Вильнюсская Академия художеств).

6. Стефан Нарембский, Деревянный костел в Креве, 1934.

7. Стефан Нарембский, Двореи архиепископа в Вильнюсе, реконструкиия 1932-1935, современное состояние.

8. Стефан Нарембский, Интерьер двориа-резиденции архиепископа в Вильнюсе, каминный зал, после 1932. Эскиз хранится в Музее архитектуры во Врочлаве.

9. Стфан Нарембский, Проект камина для зала Сената Университета Стефана Батория, 1937.

10. Стефан Нарембский, Проект реконструкции Городской Ратуши в Вильнюсе, 1937. Эскиз хранится в Художественном Музее Литвы в Вильнюсе (Lietuvos Dailès Muziejus, Vilnius).

11. Стефан Нарембский, Проект киоска для Вильнюса, начало 1941, эскиз находится в Музее архитектуры во Вроцлаве.

12. Збигнев Валь (до 1939), Стефан Нарембский (после 1945), Collegium Physicum (ныне здание факультета математики и информатики Университета Николая Коперника) в Торуни. Современное состояние.

13. Стефан Нарембский, Пресвитерий кафедрального собора Св. Яна в Торуни, реконструкция 1949.

14. Стефан Нарембский, Интерьер кафедрального собора Св. Яна в Торуни, алтарь, реконструкция 1949.

15. Стефан Нарембский, Интерьер Городской Ратуши в Торуни, реконструкция 1960-1964. 
16. Стефан Нарембский, Мебель для интерьера городской ратуши в Торуни, реконструкция 1960-1964.

17. Стефан Наремюский, Интерьер бара «Под синим фартуком» в Торуни, после 1946.

18. Стефан Нарембский. (1892-1966), около 1960 г. в Торуни. Фотография в: Архиве Университета Николая Коперника в Торуни (Archiwum UMK w Toruniu, K-9/360, Akta osobowe. Narębski Stefan, 1945-1962). 
Для заметок 
Научное издание

Червонная Светлана Михайловна

МЕЖДУ РОССИЕЙ, ЛИТВОЙ И ПОЛЬШЕЙ:

СУДЬБА ХУДОЖНИКА ВИЛЬНЮССКОЙ ШКОЛЫ ХХ ВЕКА (ЖИЗНЬ И ТВОРЧЕСТВО СТЕФАНА НАРЕМБСКОГО)

\author{
Монография
}

Чебоксары, 2020 г.

Компьютерная верстка и правка А.А. Кузьмина

Дизайн обложки H.B. Фирсова

Подписано в печать 06.08.2020 г.

Дата выхода издания в свет 11.08.2020 г.

Формат 60×84/16. Бумага офсетная. Печать офсетная.

Гарнитура Times. Усл. печ. л. 4,65. Заказ К-683. Тираж 500 экз.

Издательский дом «Среда»

428005, Чебоксары, Гражданская, 75, офис 12

+7 (8352) 655-731

info@phsreda.com

https://phsreda.com

Отпечатано в Студии печати «Максимум»

428005, Чебоксары, Гражданская, 75

+7 (8352) 655-047

info@maksimum21.ru

www.maksimum21.ru 